\title{
Canadian snow and sea ice: historical trends and projections
}

\author{
Lawrence R. Mudryk ${ }^{1}$, Chris Derksen ${ }^{1}$, Stephen Howell ${ }^{1}$, Fred Laliberté ${ }^{1}$, Chad Thackeray ${ }^{2}$, \\ Reinel Sospedra-Alfonso $^{3}$, Vincent Vionnet ${ }^{4}$, Paul J. Kushner ${ }^{5}$, and Ross Brown ${ }^{6}$ \\ ${ }^{1}$ Climate Research Division, Environment and Climate Change Canada, Toronto, Canada \\ ${ }^{2}$ Department of Geography and Environmental Management, University of Waterloo, Waterloo, Canada \\ ${ }^{3}$ Climate Research Division, Environment and Climate Change Canada, Victoria, Canada \\ ${ }^{4}$ Centre National de Recherches Météorologiques, Centre d'Etudes de la Neige, Grenoble, France \\ ${ }^{5}$ Department of Physics, University of Toronto, Toronto, Canada \\ ${ }^{6}$ Climate Research Division, Environment and Climate Change Canada, Montréal, Canada
}

Correspondence: Lawrence R. Mudryk (lawrence.mudryk@canada.ca)

Received: 6 September 2017 - Discussion started: 9 October 2017

Revised: 9 February 2018 - Accepted: 20 February 2018 - Published: 4 April 2018

\begin{abstract}
The Canadian Sea Ice and Snow Evolution (CanSISE) Network is a climate research network focused on developing and applying state of the art observational data to advance dynamical prediction, projections, and understanding of seasonal snow cover and sea ice in Canada and the circumpolar Arctic. Here, we present an assessment from the CanSISE Network on trends in the historical record of snow cover (fraction, water equivalent) and sea ice (area, concentration, type, and thickness) across Canada. We also assess projected changes in snow cover and sea ice likely to occur by mid-century, as simulated by the Coupled Model Intercomparison Project Phase 5 (CMIP5) suite of Earth system models. The historical datasets show that the fraction of Canadian land and marine areas covered by snow and ice is decreasing over time, with seasonal and regional variability in the trends consistent with regional differences in surface temperature trends. In particular, summer sea ice cover has decreased significantly across nearly all Canadian marine regions, and the rate of multi-year ice loss in the Beaufort Sea and Canadian Arctic Archipelago has nearly doubled over the last 8 years. The multi-model consensus over the 2020 2050 period shows reductions in fall and spring snow cover fraction and sea ice concentration of 5-10\% per decade (or $15-30 \%$ in total), with similar reductions in winter sea ice concentration in both Hudson Bay and eastern Canadian waters. Peak pre-melt terrestrial snow water equivalent reductions of up to $10 \%$ per decade $(30 \%$ in total) are projected across southern Canada.
\end{abstract}

\section{Introduction}

Seasonal terrestrial snow and sea ice influence short-term weather and longer-term climate by altering the surface energy budget, modifying both the surface reflectivity and thermal conductivity (Serreze et al., 2007; Flanner et al., 2011; Gouttevin et al., 2012). Snow also influences freshwater storage through soil moisture recharge and surface runoff (Barnett et al., 2005). Understanding historical and projected changes to snow and ice is essential to assess both the importance of physical changes to the climate system and their consequent impacts and risks. A previous assessment of the Canadian cryosphere (snow, sea ice, freshwater ice, land ice, frozen ground) was compiled as part of the International Polar Year (IPY) in 2007-2008 and is described in Derksen et al. (2012). The current study updates the IPY analysis pertaining to terrestrial snow and sea ice by adding nearly a decade of data and including climate model projections of changes over the next 30 to 40 years. This study is focused on Canadian territory, which is nearly completely covered by snow and sea ice for parts of each year with nearcontinuous coverage over high-latitude and high-elevation regions. Snow and sea ice are recognized as critical components of Canada's natural environment, ecosystems, and economy. With respect to snow cover, real-time information on the amount of snow on the ground (i.e. depth and water equivalent) is used in operational decision making for water resource planning (Turcotte et al., 2007), snow clearing, evaluation of avalanche risk (Conlan and Jamieson, 2017), 
and initialization of Canada's global weather forecast system (Brasnett, 1999). Historical snow cover data are used in a wide range of applications including ecological studies (Luus et al., 2013), water resources (Kang et al., 2014), forest management (Hanewinkel et al., 2008), estimation of snow loads for infrastructure design (Hong and Ye, 2014), impacts on ground frost penetration (Zhang et al., 2008), and evaluation of climate and hydrological models (Verseghy et al., 2017; Ganji et al., 2017). Snow also makes a significant direct contribution to the Canadian economy through winter recreation (Archambault et al., 2003 as cited in Scott et al., 2007). With respect to sea ice, knowledge of both historical and future sea ice conditions in Canadian waters is important for operational ship navigation to ensure economic and safe shipping, particularly in the Northwest Passage. In addition, information on sea ice (e.g. coverage, type, and thickness) is required for the initialization and verification of seasonal prediction models (Lindsay et al., 2012; Sigmond et al., 2013). While acknowledging the Canadian focus, much of the applied approach will be extended to other regions of interest through upcoming Coupled Model Intercomparison Project Phase 6 (CMIP6) experiments (Eyring et al., 2016).

Previous studies have shown that warming temperatures, which are amplified at higher latitudes as a natural response to increasing greenhouse gases (Serreze et al., 2009; Pithan and Mauritsen, 2014), reduce the spatial extent and mass of snow and ice (for example, see Derksen et al., 2012). In reality, the linkage between warming temperatures and snow-sea ice reduction is more nuanced due to the following:

- Regional and seasonal climate variability. For example, surface temperature warming across Canadian land and ocean areas is not uniform in space and time, but contains regional and seasonal variability driven by natural climatic processes, such as the El Niño-Southern Oscillation (ENSO) and other oceanic teleconnections as well as inter-seasonal and inter-annual changes in the preferred modes of atmospheric circulation (Vincent et al., 2015). The impact of warm temperature departures on the cryosphere varies with season: during spring they are directly linked to the timing and magnitude of melt onset, while during fall warm temperatures can be associated with delayed snow cover onset and ice formation, the impacts of which may not become apparent for many months.

- The selection of cryospheric variables. The onset, accumulation/growth and melt of snow and sea ice are influenced by many factors. Different metrics are relevant for assessing different impacts on the environment and ecosystems, and these metrics do not always vary coherently with each other (Bokhorst et al., 2016). Changes in snow can be reflected in the timing of snow onset in the fall and melt in the spring, the annual maximum accumulation of snow mass, or the extent of snow covered area. For sea ice, not only are changes in the fractional ice cover important but the type of sea ice present is as well, specifically whether it is thin first-year ice or thicker multi-year ice (Maslanik et al., 2011).

- Other process drivers. While surface temperature plays a major role in influencing snow and ice, there are other important drivers of change. For instance, increased precipitation in sufficiently cold regions may offset shorter snow seasons (Brown and Mote, 2009). Sea ice dynamics (driven by wind and ocean currents) can play a major role in regional sea ice conditions independent of surface temperature (Howell et al., 2013a).

- Snow-ice forcing of climate anomalies. Variations in snow and ice cover may also generate feedbacks to the atmosphere-ocean circulation that influence climate on seasonal to decadal scales (Cohen et al., 2007; Smith et al., 2010; Scaife et al., 2014), although there is no clear consensus on how changes in Arctic sea ice and snow cover influence midlatitude climate (Francis and Vavrus, 2012, 2015; Francis et al., 2017; Barnes, 2013; Screen et al., 2015).

The first objective of this paper is to provide an overview of observed changes to seasonal terrestrial snow and sea ice across Canadian territory using the longest available time series of validated gridded datasets. We use a multi-dataset approach, averaging multiple estimates of terrestrial snow variables together for more robust trends and using an integrated, multi-source dataset for analysis of sea ice change. The second objective is to compare these recent historical changes to projected changes of snow and sea ice over a similar length of time from the near future to the middle of the 21 st century (2020-2050). We use simulations from state of the art climate models with confidence levels that account for uncertainty in the regional temperature response (note that the focus of this study is not model evaluation - that analysis is described in Kushner et al., 2018, which is a companion paper to this study). Results are presented in two sub-sections, separated by the observational analysis period (Sect. 3.1) and the climate projections (Sect. 3.2). Details on the datasets and methodology are provided in Sect. 2. We summarize our key findings in Section 4 and present remaining points of discussion in Sect. 5.

\section{Data}

\subsection{Historical datasets}

\subsubsection{Terrestrial snow data}

Following Mudryk et al. (2015), we took a multi-dataset approach to analyze observed snow cover change in order to account for observational uncertainty. We calculated monthly snow cover fraction (SCF) and annual maximum snow water equivalent (SWEmax) using daily SWE data taken from 
the following four sources over the 35-year period from 1981 to 2015. (1) The Modern-Era Retrospective Analysis for Research and Applications Version 2 (MERRA-2) (Global Modeling and Assimilation Office, 2016; Gelaro et al., 2017) is a National Aeronautics and Space Administration (NASA) atmospheric reanalysis product generated with the Goddard Earth Observing System Model, Version 5.2.0 (GEOS-5), atmospheric general circulation model and atmospheric data assimilation system (ADAS). (2) The temperature index model described by Brown et al. (2003) reconstructs daily SWE using 6-hourly temperature field and 12-hourly precipitation field inputs from ERA-Interim reanalysis. This simplified index model includes most of the temperature-dependent processes included in the snow component of numerical land surface schemes (e.g. partitioning of precipitation into solid and liquid fractions, melt from rain-on-snow events, specification of new snowfall density, snow aging, and snowmelt). (3) The physical snowpack model Crocus simulates daily SWE using meteorology from ERA-Interim (Brun et al., 2013). (4) The European Space Agency GlobSnow product (Version 2; www.globsnow.info, last access: 20 September 2016) is a gridded product derived through a combination of satellite passive microwave data, forward snow emission model simulations, and climate station observations for non-alpine regions of the Northern Hemisphere (Takala et al., 2011). The GlobSnow product is masked over regions of complex topography, defined using a high-resolution topographic map ( 5 arcmin) as regions in which the standard deviation in elevation is larger than $200 \mathrm{~m}$. This criterion affects approximately $20 \%$ of the NH land surface (principally alpine regions) and a similar percentage of the Canadian land surface. We replaced grid cells containing complex topography with a blend of the GlobSnow data and the mean value from the other three data sources. The weighting for the blend was determined by the fraction of the grid cell area containing complex topography. For grid cells with no complex topography, unaltered GlobSnow data are used. As the fraction of complex topography increases, the weight applied to the GlobSnow data is linearly reduced, reaching zero for grid cells containing only complex topography.

For a given dataset of daily SWE, we interpolated the data to a regular $0.25^{\circ}$ grid over Canada and applied a $4 \mathrm{~mm}$ threshold to produce a daily binary snow cover field. We averaged this daily field over each month to produce a monthly snow cover fraction. Annual maximum SWE fields were calculated as the maximum value of daily SWE attained at each grid location over a given snow season. For both SCF and SWEmax, we computed trends separately for each of the four datasets and then averaged these together into a final trend representing the mean across the observational ensemble.

\subsubsection{Sea ice data}

For our analysis of changes in sea ice we examined monthly and seasonal changes in sea ice concentration (SIC) and sea ice thickness. SIC is analogous to our SCF derivation, in that it represents the fraction of the surface that is covered by sea ice but can also be interpreted as the fraction of time over which the surface is fully ice-covered. We extracted total and multi-year ice (MYI) area within Canadian Arctic waters from the Canadian Ice Service Digital Archive (CISDA), which is an integration of a variety of datasets including satellite observations, surface observations, airborne and ship reports, operational model results, and the expertise of ice analysts (see Canadian Ice Service, 2007, and Tivy et al., 2011a, for complete details). We selected the CISDA record instead of satellite passive microwave data because (1) the CISDA was found to be more accurate in the shoulder seasons during which passive microwave retrievals can underestimate sea ice concentration by as much as $44 \%$ (Agnew and Howell, 2003) and (2) the CISDA sea ice record provides homogeneous data back to 1968 for regions of the Canadian Arctic (Tivy et al., 2011a), almost 10 years earlier than coverage by satellite passive microwave observations. The CISDA data were analyzed over two historical periods: the 19812015 period consistent with available snow data and a longer 1968-2016 period.

Analogous to SWE, which provides a metric for the total amount of snow, we also analyzed maximum landfast sea ice thickness. We used the Canadian Ice Service record of in situ landfast ice thickness measurements, made regularly at coastal Arctic stations since the early 1950s (Howell et al., 2016b). In general, thickness measurements are available at weekly frequency, starting after freeze-up when the ice is safe to walk on and continuing until breakup or when the ice becomes unsafe. Details of this dataset are provided by Brown and Cote (1992) and are available on the Canadian Ice Service website at http://ice-glaces.ec.gc.ca/ (last access: 1 August 2017).

\subsubsection{Surface temperature}

In light of documented differences in gridded temperature datasets over Canada (Rapaic et al., 2015), surface temperature trends were derived from a blend of six reanalysis products: the European Centre for Mid-Range Weather Forecasting (ECMWF) reanalysis (ERA-Interim, 2017; Dee et al., 2011), the Japanese 55- and 25-year reanalyses (JRA55, Japan Meteorological Agency (JMA), 2017; Kobayashi et al., 2015; JRA-25, Japan Meteorological Agency (JMA) and the Central Research Institute of Electric Power Industry (CRIEPI), 2017; Onogi et al., 2007), the Modern-Era Retrospective analysis for Research and Applications versions 1 and 2 (MERRA-1, Global Modeling and Assimilation Office, 2017a; Rienecker et al., 2011; MERRA-2, Global Modeling and Assimilation Office, 2017b; Gelaro et al., 
Table 1. List of CMIP5 models (with number of realizations) used for terrestrial snow analysis of both historical and future periods.

\begin{tabular}{lr}
\hline Model & No. \\
\hline BCC-CSM1.1 & 1 \\
BNU-ESM & 1 \\
CanESM2 & 5 \\
CCSM4 & 6 \\
CNRM-CM5 & 5 \\
CSIRO-Mk3.6.0 & 10 \\
FGOALS-g2 & 1 \\
GISS-E2-R & 1 \\
INM-CM4 & 1 \\
MIROC5 & 3 \\
MIROC-ESM & 1 \\
MPI-ESM-LR & 3 \\
MRI-CGCM3 & 1 \\
NorESM1-ME & 1 \\
NorESM1-M & 1 \\
\hline
\end{tabular}

2017), and the Climate Forecast System Reanalysis (CFSR, NOAA/National Weather Service, 2017; Saha et al., 2010). The average trend was determined by first computing the average of JRA-55 and JRA-25 (resulting in a single JRA trend) and the average of MERRA-1 and MERRA-2 (resulting in a single MERRA trend). The multi-reanalysis mean trend was computed by averaging (ERA-Interim, CFSR, JRA, and MERRA). Reanalysis was used instead of point station data in order to produce spatially continuous trends over both terrestrial and marine areas.

\subsection{Model simulations}

\subsubsection{Terrestrial snow}

We used monthly mean output from the suite of historical and future simulations from the CMIP5 archive (Taylor et al., 2012; http://cmip-pcmdi.llnl.gov/cmip5/, last access: 20 July 2017) to evaluate SCF (denoted as "snc" in CMIP5 output) and SWE (denoted as "snw" in CMIP5 output). The models utilized for snow analysis are listed in Table 1; note that no model selection was performed - all models with archived snow data were utilized. The resolution of available atmospheric-land model output ranges from approximately $1.3^{\circ} \times 0.9^{\circ}$ to $2.8^{\circ} \times 2.8^{\circ}$ longitude and latitude. Snow projections were selected from the Representative Concentration Pathway (RCP) 8.5 projected forcing scenario because it most closely resembles the observed emissions pathway over the past decade (Peters et al., 2012). We then computed individual trends for each realization and then took the interrealization average across each model to calculate individual model ensemble means. These values were averaged to determine the CMIP5 multi-model mean values. If only a single realization was available, that was used directly as input to the multi-model mean calculation. SWE and SCF output
Table 2. List of CMIP5 models (with number of realizations) used for sea ice analysis of both historical and future periods.

\begin{tabular}{lrlr}
\hline Model & No. & Model & No. \\
\hline BCC-CSM1-1 & 1 & MIROC5 & 3 \\
BCC-CSM-1-m & 1 & HadGEM2-CC & 1 \\
BNU-ESM & 1 & HadGEM2-ES & 4 \\
CanESM2 & 5 & MPI-ESM-LR & 3 \\
CMCC-CESM & 1 & MPI-ESM-MR & 1 \\
CMCC-CM & 1 & MRI-CGCM3 & 1 \\
CMCC-CMS & 1 & MRI-ESM1 & 1 \\
CNRM-CM5 & 5 & GISS-E2-H & 1 \\
ACCESS1.0 & 1 & GISS-E2-H-CC & 1 \\
ACCESS1.3 & 1 & GISS-E2-R & 5 \\
CSIRO-Mk3.6.0 & 10 & GISS-E2-R-CC & 1 \\
FIO-ESM & 1 & CCSM4 & 6 \\
EC-EARTH & 11 & NorESM1-M & 1 \\
inmcm4 & 1 & NorESM1-ME & 1 \\
IPSL-CM5A-LR & 4 & HadGEM2-AO & 1 \\
IPSL-CM5A-MR & 1 & GFDL-CM3 & 1 \\
IPSL-CM5B-LR & 1 & GFDL-ESM2G & 1 \\
FGOALS-g2 & 1 & GFDL-ESM2M & 1 \\
FGOALS-s2 & 1 & CESM1(BGC) & 1 \\
MIROC-ESM & 1 & CESM1(CAM5) & 3 \\
MIROC-ESM-CHEM & 1 & CESM1-CAM5-1-FV2 & 1 \\
\hline
\end{tabular}

was also taken from a large initial condition ensemble (50 realizations) of the second-generation Canadian Earth System Model (CanESM2; Arora et al., 2011), a global Earth system model from the Canadian Centre for Climate Modelling and Analysis. Each of the realizations of this ensemble evolves over the 1950-2100 period under identical historical radiative forcings in accordance with CMIP5 from 1950 to 2005 and the RCP8.5 scenario from 2006 to 2100 (see Thackeray et al., 2016, for more details). As such, differences among realizations result only from differences in the initial climate state and are due to natural variability alone. This ensemble was used to characterize the role of internal climate variability on projected snow cover changes over Canada.

\subsubsection{Sea ice}

Monthly mean sea ice concentration (denoted as "sic" in CMIP5 output) and the land-sea mask (denoted as "sftlof" in CMIP5 output) were also retrieved as available from CMIP5 output resulting in a sea ice ensemble that comprises 42 models and a combined total of 91 simulations (Table 2). The resolution of ocean-ice model grids are generally equal to or finer than corresponding atmospheric grids ranging from approximately $0.4^{\circ} \times 0.4^{\circ}$ to $1.0^{\circ} \times 1.0^{\circ}$ longitude and latitude. The sea ice concentration was projected to the EASE grid using the same procedure as in Laliberté et al. (2016). For projections of sea-ice-free conditions over the four Canadian marine subregions (Baffin Bay, Beaufort Sea, Canadian Arctic Archipelago (CAA), and Hudson Bay), we excluded 
models that do not capture at least $75 \%$ of the region's observed ocean area (resulting in about half of the models rejected in the CAA) and computed sea ice extent as in Laliberté et al. (2016).

\subsection{Evaluation of trend significance}

In order to make comparable significance calculations for the observed and projected trends, we use a Monte Carlo method following Swart et al. (2015) and applied in Howell et al. (2016b). The method ensures that spread due to internal variability is comparable for all CMIP5 models, even those that only include a single realization in their archived output. This is achieved by adding simulated noise representing internal variability to those models with only a single realization. The added noise is calculated from the collection of models with multiple realizations under the assumption that the spread due to internal variability is the same across all models. A trend is significantly different from zero if it is distinguishable from the combined spread due to inter-annual variability (using a $t$ distribution for each simulation), internal variability (with noise added as described), and model spread.

We use an analogous approach to compute significance for the various observation-based dataset trends. We assume that differences in the trends arise from differences in retrieval performance and reanalysis methodologies but not from sampling of internal variability. Thus, a trend is significantly different from zero if it is distinguishable from the combined spread due to inter-annual variability (using a $t$ distribution for the dataset mean) and the added spread due to differences in the trends among the different datasets.

\section{Results}

\subsection{Observed trends in terrestrial snow and sea ice}

Seasonally averaged trends in terrestrial SCF and SIC over the 1981-2015 time period are shown in Fig. 1 (the dashed line denotes limit of Canadian marine territory). Throughout the paper, we present seasonal trends for permutated months in order to more closely match the mid-season peaks of SCF (January), SWE (February-March), and SIC and sea ice thickness (March). Positive trends in SCF (more snow cover) are evident over a small region of the southern Prairies in winter (January-February-March, JFM) and more extensively over western Canada in spring (AprilMay-June, AMJ). Trends in all remaining regions and seasons are negative, notably over eastern Canada in spring and most of the Canadian land area in the fall (OctoberNovember-December, OND). The predominantly negative trends in snow cover are consistent with previous studies (Brown and Braaten, 1998; Vincent et al., 2015) but with evidence of a shift to stronger snow cover reductions in the snow onset period over eastern Canada in response to en- hanced OND warming shown in Fig. 2 (discussed below). The observed rates of snow cover change are also consistent with the recent Snow, Water, Ice, Permafrost in the Arctic (SWIPA) assessment (Brown et al., 2017) that documented annual snow cover duration changes over Arctic land areas of -2 to -4 days per decade $(\sim-1$ to $-2 \%$ per decade assuming 250 days mean snow cover). Other studies focused on Arctic snow cover (i.e. Derksen and Brown, 2012; Derksen et al., 2016) have identified spring snow cover losses that are stronger than those in Fig. 1. This difference may stem from stronger spring trends in the NOAA snow chart data record (the NOAA dataset was not used in this study due to known deficiencies in the fall period; Brown and Derksen, 2013) compared to other snow products (Mudryk et al., 2017) and stronger trends across the Eurasian Arctic compared to North America (Derksen et al., 2016).

SIC trends over Canadian waters for this period are almost exclusively negative in all seasons. Regions with the strongest SIC declines are eastern Canadian waters in winter and spring and the CAA and Hudson Bay in summer and fall, consistent with the warming patterns shown in Fig. 2. The SCF and SIC trends can be viewed collectively as changes in the timing and extent to which highly reflective snow and ice cover the Earth's surface, with important implications for the surface energy budget. There are no sharp boundaries in trends across adjacent land and ocean regions. This provides confidence in the consistency of the snow and ice datasets as well as evidence of a coherent response of snow and ice to temperature forcing across terrestrial and marine regions.

Figure 2 shows seasonal surface air temperature (TAS) trends over the 1981-2015 period computed from a blend of six atmospheric reanalysis datasets (see Sect. 2.1.3). TAS trends are generally positive, although no trends are seen throughout the northwestern portion of the country during winter and spring, and there is significant cooling over the Canadian Prairies in spring. Land areas with cooling trends are co-located with positive SCF trends in Fig. 1, although the region with positive SCF trends is slightly more extensive. The winter and spring season cooling over northwestern and central Canada is consistent with the influence of North Pacific oceanic variability over the last 35 years (Mudryk et al., 2014). Climate in this region (including temperature and precipitation, and hence snow cover) is strongly influenced by the Pacific Decadal Oscillation (a) pattern of sea surface temperatures and associated sea level pressure changes in the North Pacific); observed sea surface temperature trends have been negative over the last 35 years, consistent with reduced warming and increased snow evident in the SCF trend patterns presented here. The reanalysis TAS trends are also seasonally and spatially consistent with the analysis of Rapaic et al. (2015, Fig. 13) based on blended data from both homogenized station observations and multiple reanalyses. In both reanalysis and in situ data, Arctic trends are strongest in the fall and winter, with an increase in the magnitude of warming 

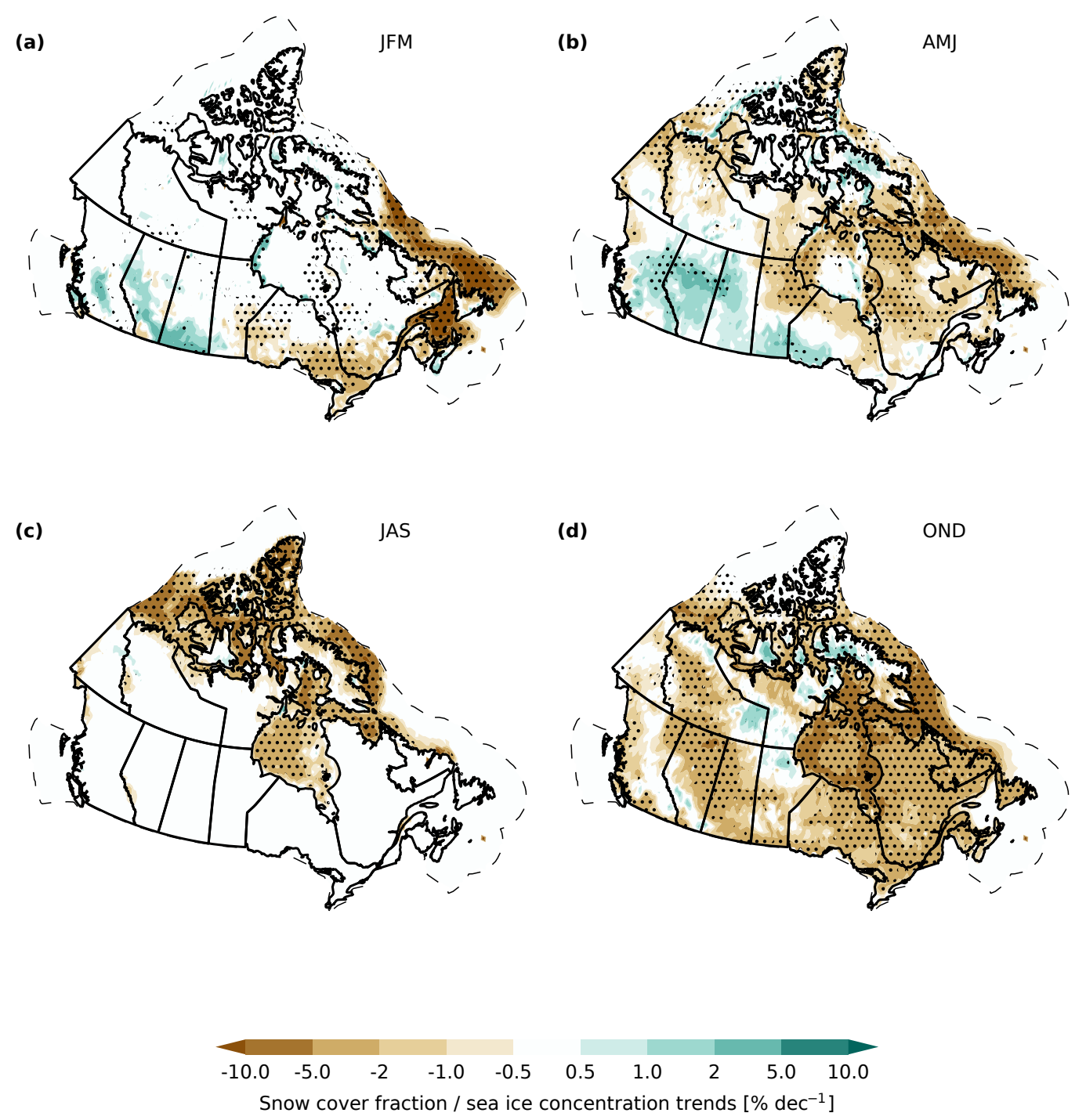

Figure 1. Terrestrial snow cover fraction and sea ice concentration trends for 1981-2015. Datasets are described in Sect. 2.1. Stippling indicates pointwise significance at the 90th percentile. Dashed line denotes limit of Canadian marine territory.

from the southwestern to northeastern regions of the country apparent in all seasons.

To examine the role of air temperature trends in driving the observed snow and ice cover trends, spatial correlations (centred and uncentred) were calculated to quantify the pattern relationship between SCF, SIC, and TAS trends (Fig. 3). The centred (uncentred) statistic measures the similarity of the two patterns after (without) removal of the domain mean. A large negative uncentred correlation indicates that the correlation between the two fields is negative on average, but does not require that the field patterns are congruent. A large negative centred correlation does require spatial similarity in the field patterns. Both SCF and SIC trends show large uncentred correlations for all seasons indicative of the general relationship between increasing temperatures and decreas- ing SCF and SIC. During JFM and AMJ, the large centred correlations between SCF and TAS indicate that the spatial patterns are also similar, and hence there is a strong association between SCF and TAS trends at the local scale during these seasons, with reduced connections during JulyAugust-September (JAS) and OND (consistent with Mudryk et al., 2017). SIC trend patterns are more closely associated with warming patterns during ice onset/growth (OND and JFM), but overall there is less co-variability of SIC trends with TAS trends than for SCF trends. This difference may stem from the fact that ice (especially MYI) melts more slowly than snow, and the additional influence of dynamical effects (such as wind-driven redistribution of sea ice) weakens the thermodynamically driven spatial association between SIC and TAS trends. 

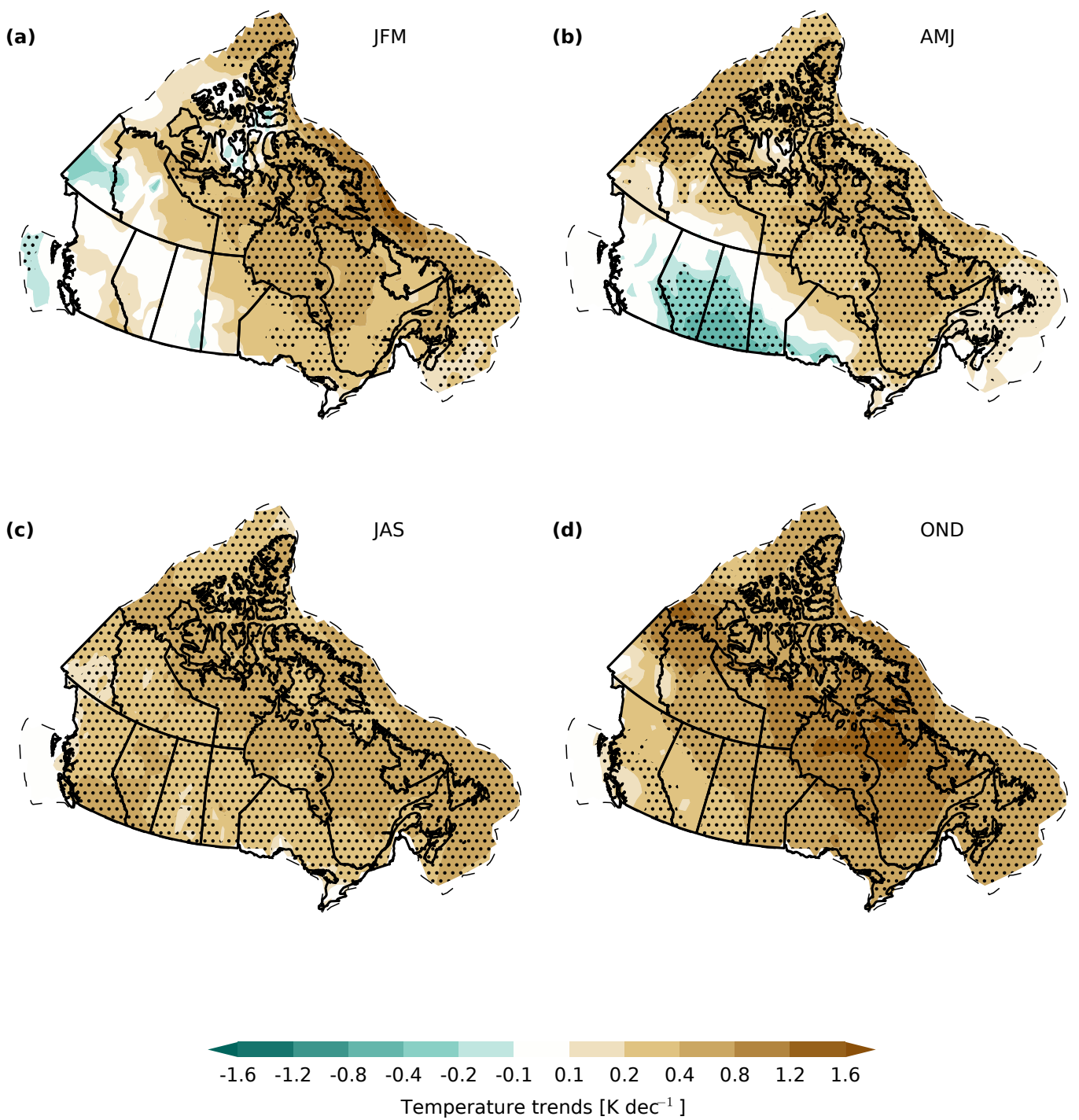

Figure 2. Trends in surface temperature, 1981-2015, from a blend of ERA-Interim, JRA-55, JRA-25, MERRA-1, MERRA-2, and CFSR reanalysis products. Stippling indicates pointwise significance at the 90th percentile.

Trends in SWEmax, which indicates water resource and streamflow potential just before spring melt, are shown in Fig. 4. The figure represents averages from the same datasets used to generate the SCF trends in Fig. 1. Trends are negative over much of Canada, indicating a reduction over time in SWEmax at the onset of the melt season each spring. Because SWE varies with the amount of accumulated snowfall, we may expect a weaker relationship to surface temperature and a stronger connection to precipitation trends. Figure 5 shows trends in annual snowfall estimated from the CANGRD dataset (Milewska et al., 2005) based on interpolated adjusted station data from Mekis and Vincent (2011) and monthly rain-snow fraction obtained from ERA-Interim 6hourly $2 \mathrm{~m}$ air temperature data assuming a $0^{\circ} \mathrm{C}$ threshold for rain-snow separation. The changes in snowfall are broadly consistent with the changes in SWE over much of Canada. Notable exceptions include the band of increased snowfall over the Northwest Territories and western Nunavut (which shows negligible or decreasing SWE trends) and the southern portion of Ontario and Québec, which shows strongly decreasing SWE trends; however, both of these regions have experienced stronger warming trends over the full snow season than the western provinces. While the changes in snowfall are generally consistent with the observed changes in SWE, it is unclear to what extent regional snowfall changes are themselves correlated with local temperature changes due to either increased melt during winter thaw events or long-term trends in the solid fraction of precipitation (for the latter see Vincent et al., 2015). We return to this discussion point at the end of Sect. 3 and again in the discussion of Sect. 4. 


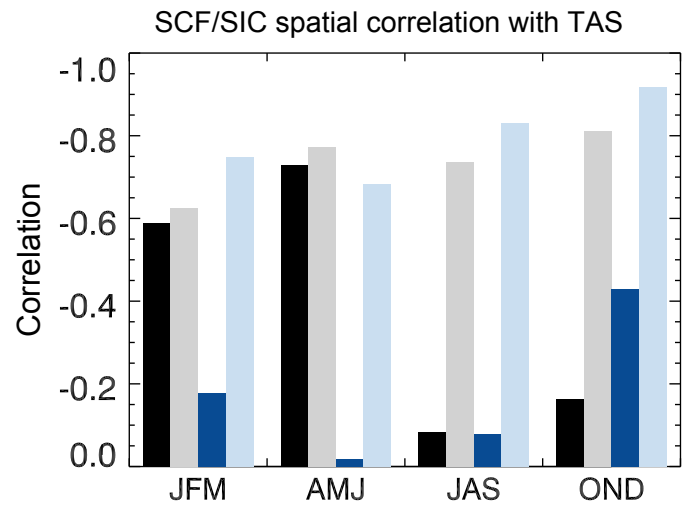

Figure 3. Centred (dark) or uncentred (light) pattern correlation between seasonal TAS trends and seasonal SCF (black) or SIC (blue) trends.

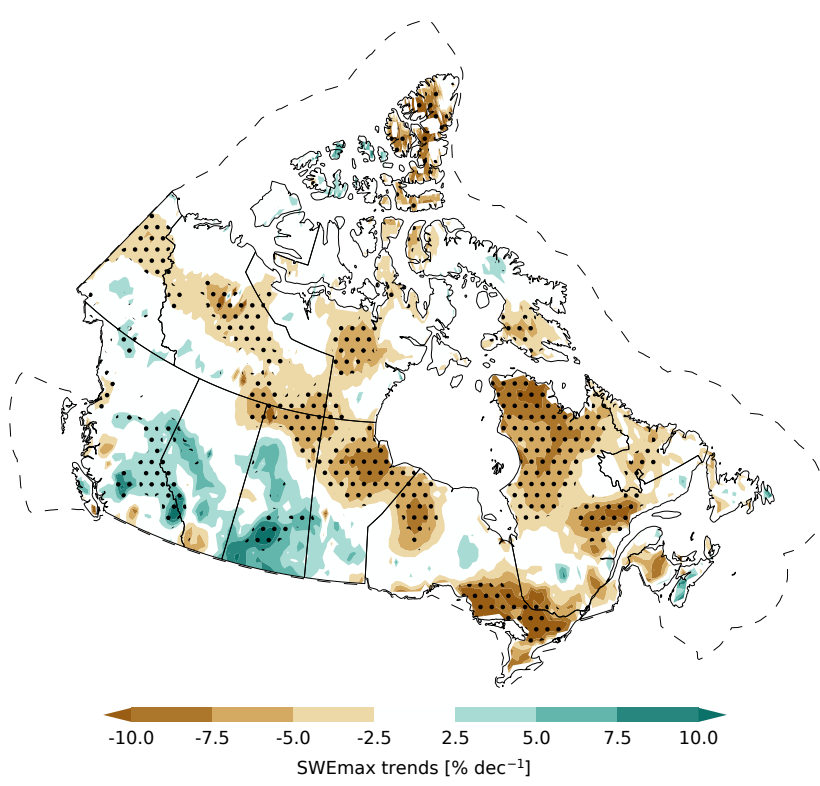

Figure 4. SWEmax trends for 1981-2015. Stippling indicates pointwise significance at the 90 th percentile.

The longer period of consistent summer sea ice information in Canadian waters from the CISDA allows consideration of additional years not covered by the 1981-2015 trends in Fig. 1. To be consistent with Tivy et al. (2011a) and Derksen et al. (2012) the summer ice season is defined as average sea ice area from 25 June to 15 October for the Beaufort Sea, CAA, and Baffin Bay regions and from 18 June to 19 November for Hudson Bay, Hudson Strait, Davis Strait, and Labrador Sea. Between 1968 and 2016, sea ice area averaged over the summer period has experienced significant decreases in almost every region of the Canadian Arctic, up to $20 \%$ per decade in some regions (e.g. the Hudson Strait and Labrador Sea; Fig. 6). Compared to previous trends reported by Tivy et al. (2011a) over the period of 1968-2008

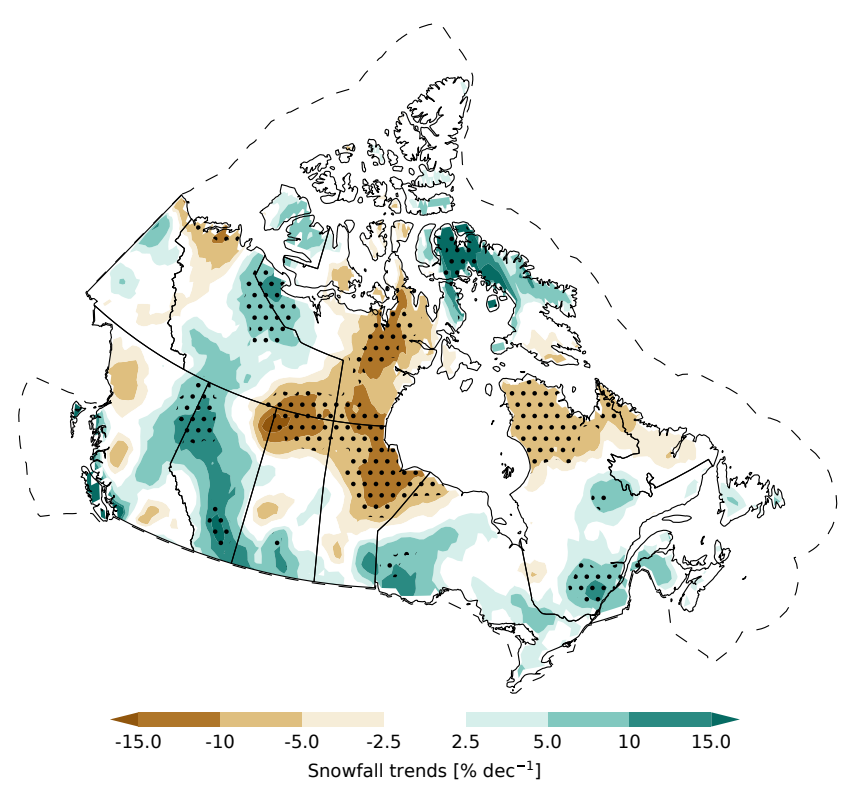

Figure 5. Snowfall trends estimated from CANGRD data. Stippling indicates pointwise significance at the 90 th percentile.

and Derksen et al. (2012) for 1968-2010, more regions are now experiencing significant decreases and the rate of decline is stronger in all regions except Hudson Bay (Fig. 7e). For MYI, there are more regions across the Canadian Arctic, particularly in the western CAA, that are now experiencing significant declines compared to previous studies (e.g. Tivy et al., 2011a; Derksen et al., 2012; Fig. 6). The largest declines in MYI occurred in the CAA and Beaufort Sea, both of which almost doubled their rate of decline for 1968-2016 when compared to the trend for 1968-2008 (Fig. 7e).

A stepwise reduction in Hudson Bay sea ice area occurred in the mid-1990s (Fig. 7d, Tivy et al., 2011b; Hochheim and Barber, 2014) and Baffin Bay has experienced consistently low sea ice area since 1999 (Fig. 7c), whereas considerably more inter-annual variability is apparent in the Beaufort Sea and CAA (Fig. 7a, b). Of note, the Beaufort Sea experienced a record low sea ice area in 2012, becoming virtually ice-free near the end of the melt season (Babb et al., 2016). This was nearly repeated in 2016. As previously reported, the CAA eclipsed the previous and long-standing record-low ice year of 1998 in both 2011 and 2012 (Howell et al., 2013b). A contributing factor to the decline of sea ice across the Canadian Arctic is increasing spring air temperature (see Fig. 2) coupled with longer melt seasons resulting in the absorption of more solar radiation and increased ice melt (Howell et al., 2009; Tivy et al., 2011a; Stroeve et al., 2014; Parkinson, 2014).

Arctic sea ice thickness has declined in recent years (e.g. Kwok and Rothrock, 2009; Haas et al., 2010; Laxon et al., 2013; Richter-Menge and Farrell, 2013; Kwok and Cunningham, 2015; Tilling et al., 2015). These studies indicate thick- 


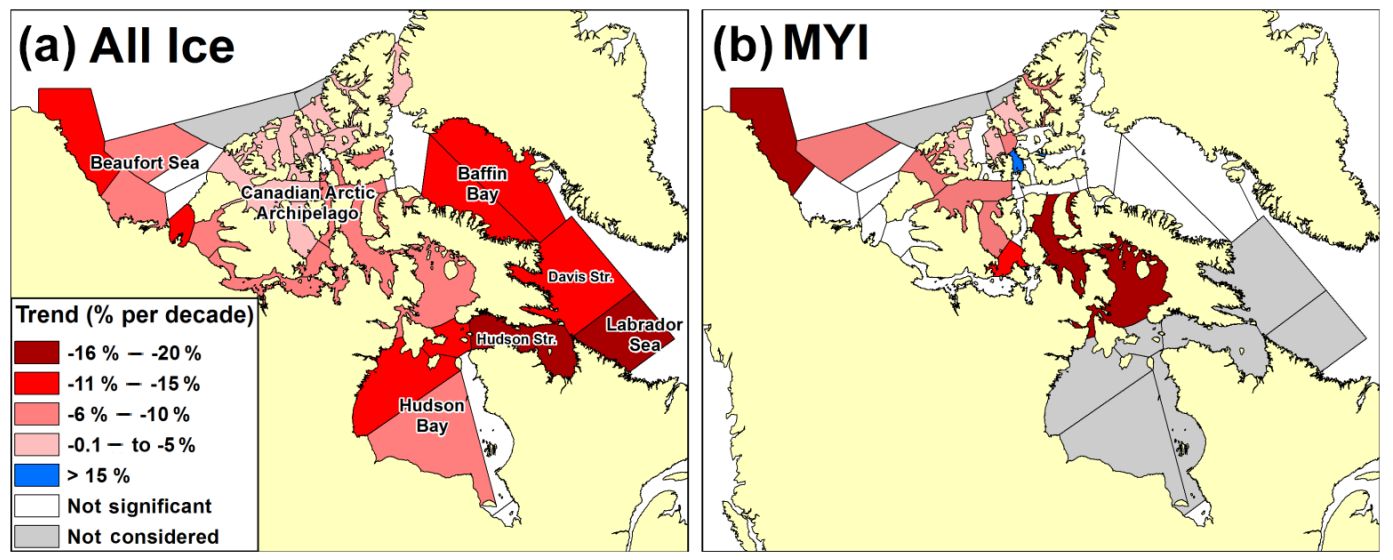

Figure 6. Trends in summer all ice (a) and multi-year ice (b) area from 1968 to 2016 from the CISDA. Only trends significant to the $95 \%$ confidence level are shown.
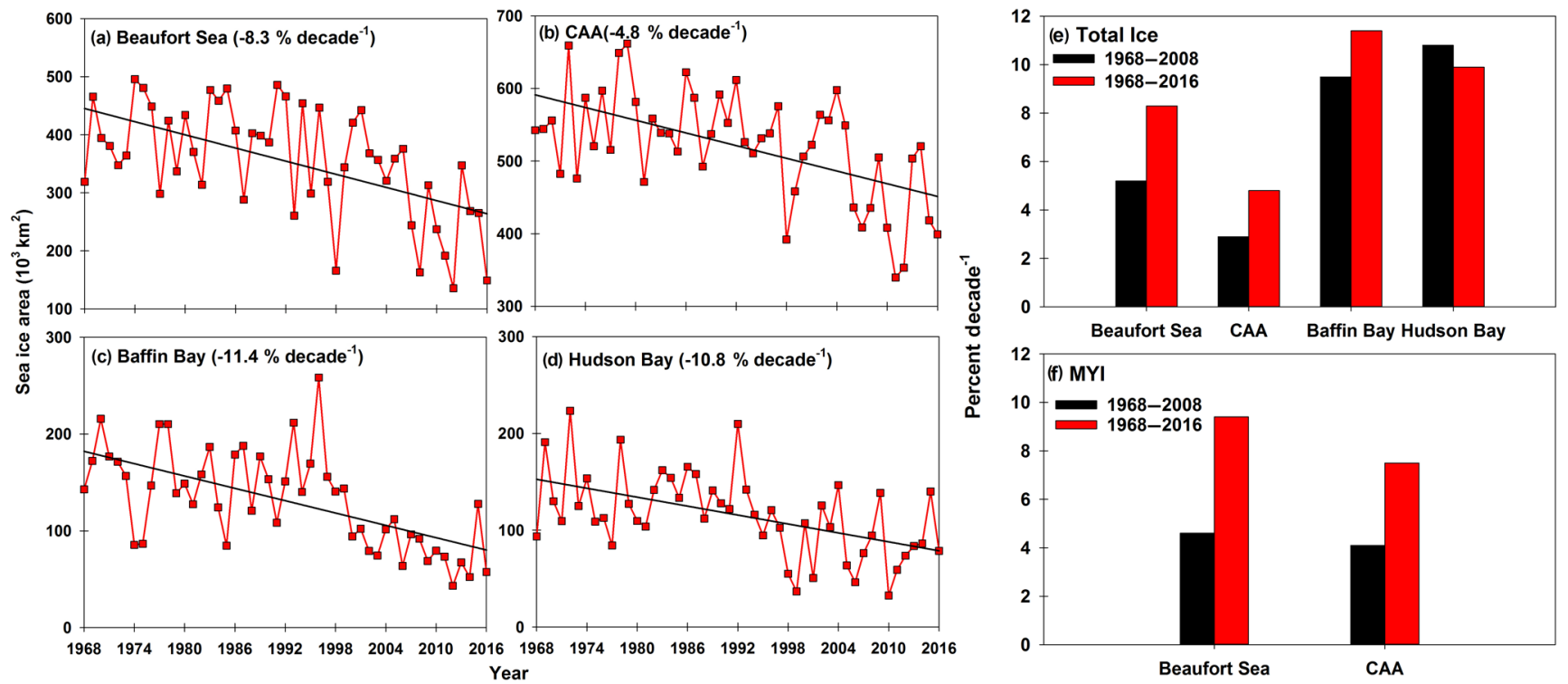

Figure 7. Time series of summer total sea ice area for the (a) Beaufort Sea, (b) Canadian Arctic Archipelago (CAA), (c) Baffin Bay, and (d) Hudson Bay regions from 1968 to 2016. Comparison of trends between 1968 and 2008 and between 1968 and 2016 for all ice (e) and multi-year ice (MYI) (f) for selected regions in the Canadian Arctic.

ness declines are greater in the Beaufort Sea compared to the north facing coast of the CAA, which still contains some of the thickest sea ice in the world. Unfortunately, the spaceborne sensors used to obtain sea ice thickness information are not of sufficient spatial resolution to provide reasonable thickness estimates within the CAA. However, the Canadian Ice Service record of in situ landfast ice thickness measurements represents one of the longest datasets in the Arctic,and spans over 5 decades (Howell et al., 2016b). However, the seasonal behaviour of landfast ice thickness can provide useful information for understanding the inter-annual variability because ice growth is almost entirely due to thermodynamic forcing. Significant declines in maximum ice thick- ness have occurred at three sites in the CAA (Cambridge Bay, Eureka, and Alert) with decreases ranging between -3.6 and $-5.1 \mathrm{~cm}$ per decade over the period from the late $1950 \mathrm{~s}$ to 2016 (Fig. 8). No significant trend was found at Resolute but an early study from Brown and Cote (1992) reported a significant increase in maximum ice thickness at Resolute over the period from 1950 to 1989.

Although systematic measurements at other regions within the CAA are unavailable or contain too much uncertainty, surveys in 2011 and 2014 of ice thickness from airborne electromagnetic induction described by Haas and Howell (2015) indicated the ice is still reasonably thick: the mode of the measured thickness distribution was $1.8-2.0 \mathrm{~m}$, and sea ice 

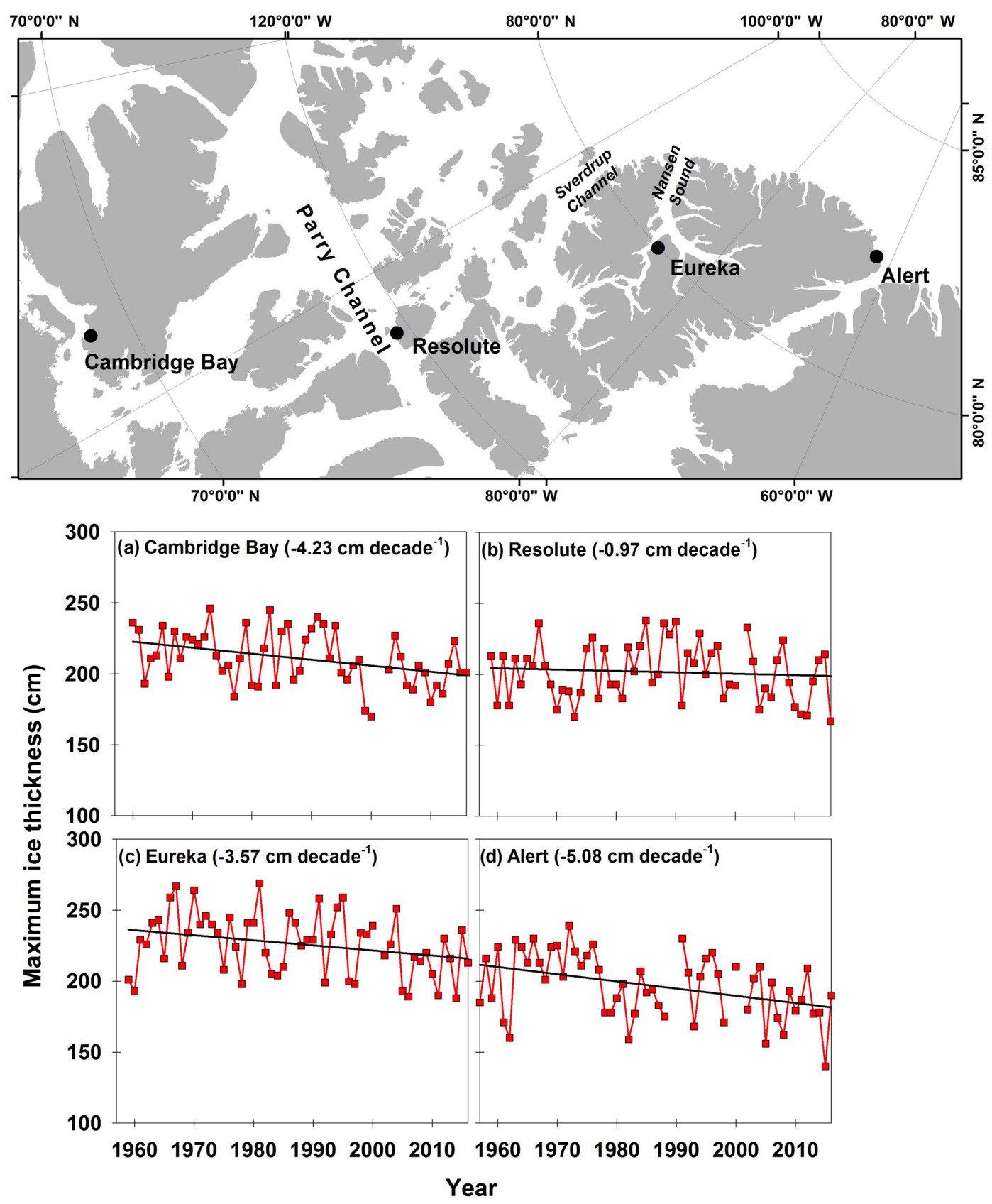

Figure 8. Time series and trend of observed maximum ice thickness at (a) Cambridge Bay, (b) Resolute, (c) Eureka, and (d) Alert locations in the Canadian Arctic.

between 3 and $4 \mathrm{~m}$ in mean thickness was found in the MYI regions throughout the CAA.

\subsection{Projected changes in terrestrial snow and sea ice}

Projected trends in SCF and SIC for the 2020-2050 time period across Canadian territory are shown in Fig. 9. These projections are the multi-model mean from the ensemble of CMIP5 climate models, using the RCP8.5 forcing scenario (which assumes "business as usual" continued growth of greenhouse gas emissions through the 21 st century). While other scenarios exist, projections to the mid-century are primarily dependent on natural variability and model-dependent uncertainties rather than the choice of forcing scenario. For example, Fig. 4 from Hawkins and Sutton $(2009,2011)$ suggest that scenario uncertainty contributes less than $10 \%$ of the total uncertainty (natural variability, model uncertainty and scenario uncertainty) for regional-scale, decadal mean temperature at a lead time of 30 years and substantially less than $10 \%$ for regional-scale precipitation. The multi-model 

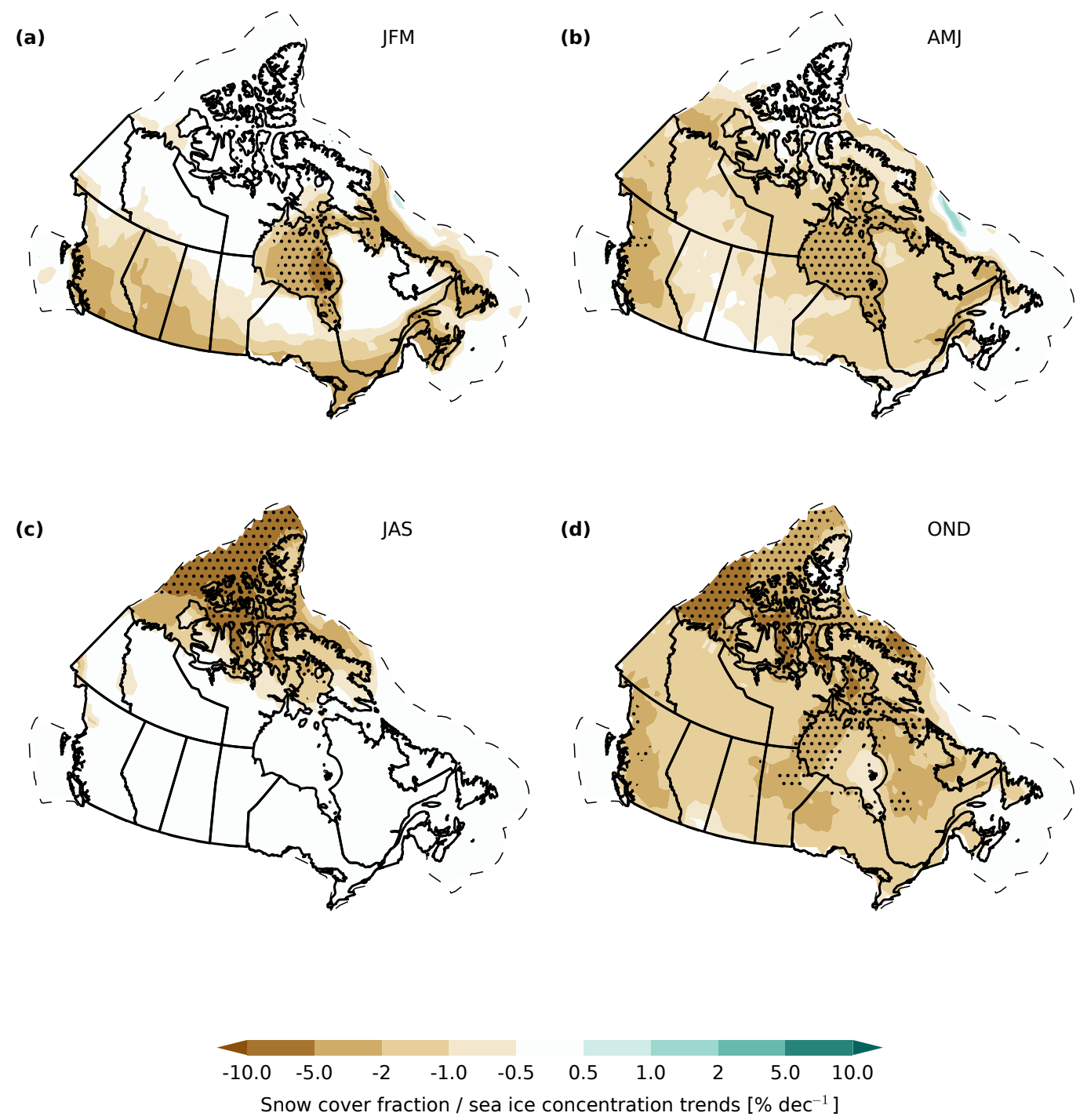

Figure 9. Projected terrestrial snow cover fraction and sea ice concentration trends for 2020-2050. Model simulations are described in Sect. 2.2. Stippling indicates pointwise significance at the 90th percentile.

projected mean changes in surface temperature are positive in all seasons, and hence only reductions in ensemble-mean SCF and SIC are evident in Fig. 9. Seasonal differences and varying sensitivity of snow and ice to temperature forcing drives the spatial variability seen in Fig. 9. During winter, projected snow cover reductions are greatest along the southern margins of Canada, where temperature increases directly result in less snow. Temperatures remain sufficiently cold at higher latitudes (despite projected warming) so there is no projected response in this region in JFM SCF. During spring, the region of snow sensitivity to temperature forcing shifts north, across the boreal forest, subarctic, and Arctic tundra, which leads to the negative SCF trends projected across these regions during AMJ. Ensemble-mean reductions projected for SIC are very strong and focused on the ice melt (sum- mer) and ice formation (fall) seasons, with the exception of Hudson Bay and eastern Canadian waters, which also have projected winter season loss of sea ice cover.

While natural decadal-scale climate variability resulted in cooling trends (and hence positive SCF and SWEmax trends) for some regions and seasons during the 1981-2015 period (see Figs. 1, 2, and 4), over the longer 1948-2012 period observed surface temperature trends over Canada are almost exclusively positive (Vincent et al., 2015). Similarly, we expect there could be short-term, localized fluctuations in trend direction and magnitude from the projections shown in Fig. 9. These localized fluctuations exist in individual realizations of the model projections (not shown) and act to increase the spread in the TAS, SCF, and SIC responses. This spread reduces the significance of the ensemble-mean 


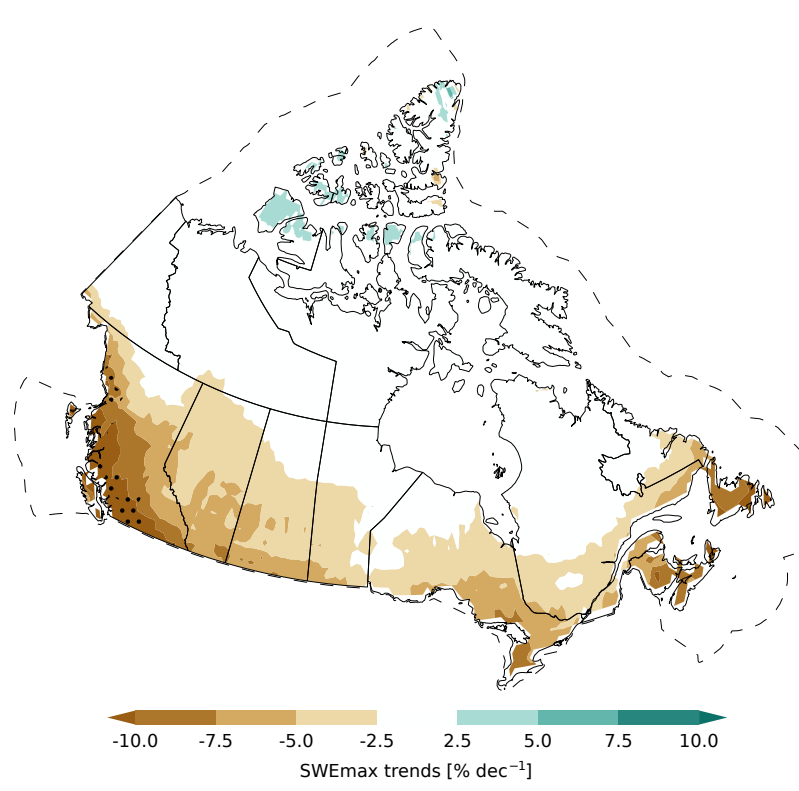

Figure 10. 2020-2050 trends in SWEmax from the CMIP5 ensemble. Stippling indicates pointwise significance at the 90th percentile. We show percent change relative to the climatological (1981-2015) mean because there is large variability in SWEmax across the country (high SWE in the Western Cordillera; low SWE in the Prairies).

response for a given confidence level; for this reason only the coastal regions in British Columbia show significant SCF decreases at the $90 \%$ confidence level, whereas projections show widespread reductions in SIC at the $90 \%$ confidence level. The differences between SCF and SIC in the significance of their projected responses may result from varying sensitivity to temperature forcing if SCF depends more strongly on the local temperature response than SIC.

Figure 10 shows trends in SWEmax also derived from the CMIP5 multi-model ensemble. The ensemble mean shows that SWEmax loss will be extensive $(5-10 \%$ per decade through 2050 , or a cumulative $15-30 \%$ reduction over the entire 2020-2050 period) over much of Alberta and British Columbia, and similarly in Southern Ontario and the Maritime provinces (note that the greatest near-future loss in the CMIP5 ensemble occurs just south of the Canadian border, not shown in Fig. 10). While positive Arctic SWEmax trends start to emerge by mid-century in the Eurasian Arctic (not shown; see Brown et al., 2017) minimal change is projected across high-latitude land areas of Canada. This may result because increasing temperature (which shortens the snow accumulation season) balances projected increases in snowfall.

Month-by-month projected changes in Canadian snow cover extent (total area of snow cover summed over the Canadian land region) and snow mass (determined by multiplying the density of water by the total volume of SWE summed over the Canadian land region) for the CMIP5 multi-model ensemble and the large initial condition ensemble from the CanESM2 are shown in Fig. 11. The two ensembles agree that the greatest near-future snow loss (as a percentage of climatological snow) is projected to occur in the shoulder seasons (October-November, May-June). During mid-winter there is minimal percentage change in snow cover extent projections because winter temperatures over northern regions of Canada will remain cold enough to sustain snow cover and there is greater climatological snow extent in winter, which results in smaller percentage changes reflected in Fig. 11. The projected trends from CMIP5 are similar in magnitude to the rate of change during the historical period considered in this study, while trends from CanESM2 are slightly stronger due to greater warming in CanESM2 compared to the CMIP5 multi-model mean (Thackeray et al., 2016). Because the CMIP5 ensemble includes many different models, there is a greater spread in most months than the CanESM2LE (large ensemble), which represents multiple climate realizations generated from a single model. Nonetheless, it is striking that the interquartile range of the CanESM Large Ensemble is quite comparable to that of the CMIP model ensemble. This likely indicates that a large portion of the CMIP5 inter-model spread is associated with internal variability, a similar result to Mudryk et al. (2017).

Sospedra-Alfonso and Merryfield (2017) showed that the inter-annual variability in monthly SWE between January and April can be skillfully estimated with a multiple linear regression model based on precipitation and temperature predictors. This statistical model suggests coherent relationships that provide context to the character of the changes to terrestrial snow cover and SWE that are being considered here. An important aspect of their analysis is that mutual correlations between precipitation and temperature variability are accounted for when analyzing their effects on SWE variability. One of their key results was that regimes where SWE variability is dominated by temperature variability and those where it is dominated by precipitation variability can be estimated using a diagnostic temperature metric. This diagnostic temperature $\left(T_{\mathrm{d}}\right)$ is illustrated for the month of March in Fig. 12 for both present-day (1981-2015) and mid-century projections (2016-2050). The diagnostic temperature is approximated by the average near-surface air temperature averaged over the consecutive months from snow onset up to the month under consideration. A temperature threshold, $T_{\text {th }}$, divides March SWE into two regions characterized by their sensitivity to precipitation and temperature variability; the region where $T_{\mathrm{d}}<T_{\text {th }}$ has March snowpack variability driven mainly by precipitation, whereas the region where $T_{\mathrm{d}}>T_{\text {th }}$ has temperature-driven March snowpack variability. The division between these two regions differs depending on the month under consideration (for example, the extent of the precipitation dominated region decreases during spring when the diagnostic temperature isotherms shift northward), and the temperature threshold varies slightly depending on the time period under consideration but is generally found between $T_{\text {th }}=-5 \pm 1^{\circ} \mathrm{C}$. See Sospedra-Alfonso and Merryfield (2017) for further details. 

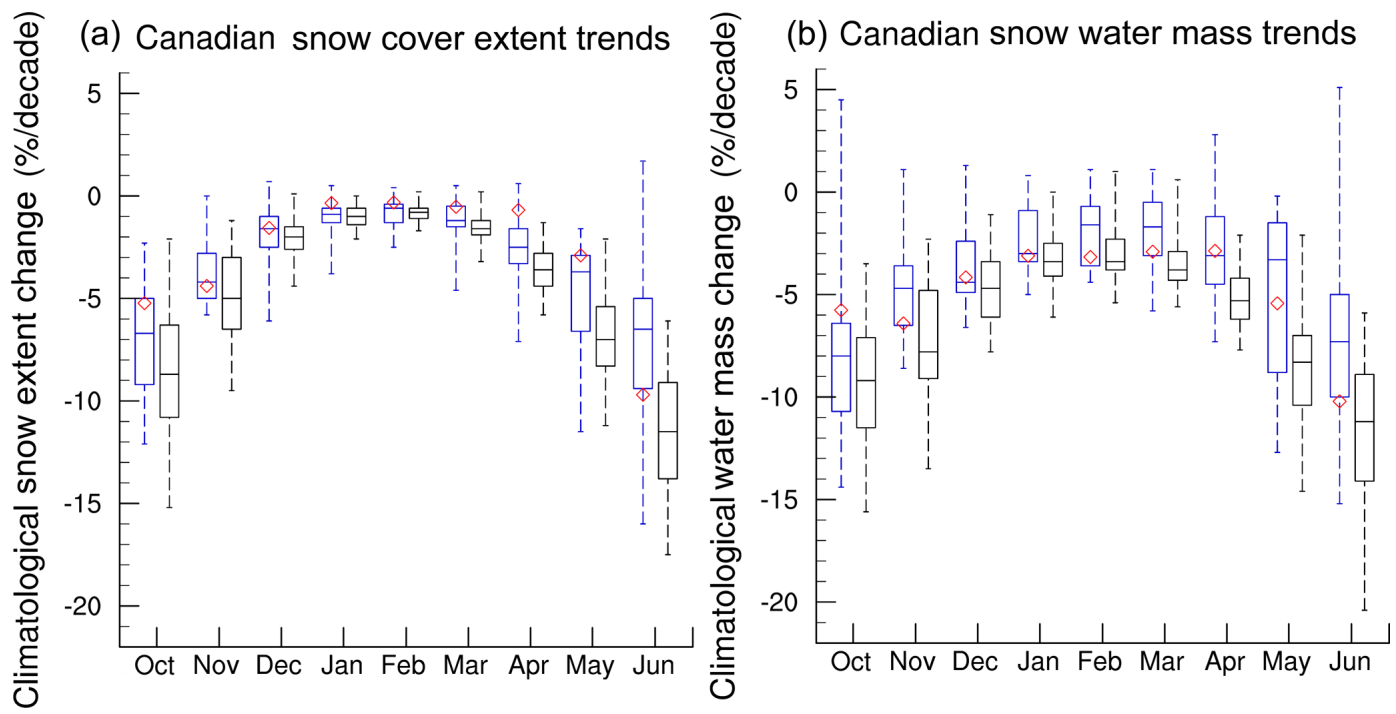

Figure 11. 2020-2050 monthly trends in Canadian snow cover extent (a) and snow water mass (b) from the CMIP5 multi-model ensemble (blue) and CanESM large initial condition ensemble (black). Monthly mean observational trends (1981-2015) from the snow dataset used in Sect. 2 are shown in red. For each box the enclosed region shows the 25-75th percentile range, the horizontal line shows the median, and the dashed whiskers illustrate the minimum and maximum.

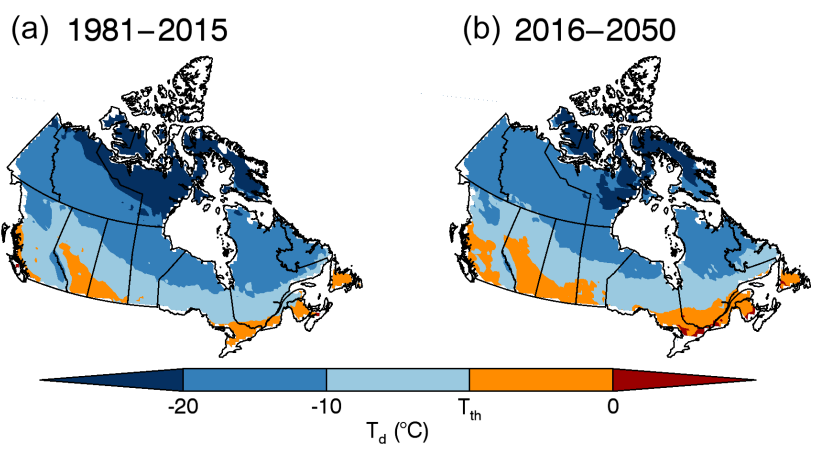

Figure 12. Temperature and precipitation controls on March snow water equivalent for historical period (a) and projections to 2050 (b). For the data presented here $T_{\text {th }}=-5.4{ }^{\circ} \mathrm{C}$ (more generally $T_{\text {th }}=-5 \pm 1{ }^{\circ} \mathrm{C}$ ). Regions with $T_{\mathrm{d}}<T_{\text {th }}$ (blue) have March SWE dominated by precipitation variability while regions with $T_{\mathrm{d}}>T_{\text {th }}$ (orange) have March SWE dominated by temperature variability.

In 1981-2015, regions with temperature-dominated March snowpack $\left(T_{\mathrm{d}} \stackrel{\sim}{>}-5^{\circ} \mathrm{C}\right)$ include coastal British Columbia, southern Alberta, southwest Saskatchewan, southern margins of the St. Lawrence River and the Great Lakes, the Maritime provinces, and Newfoundland. Because of the projected warming, the seasonal isotherms shift northward and toward higher elevations, extending the portion of the snow cover that is more sensitive to temperature variations. By 2016-2050, regions with temperature-driven snowpack also include most of southern Canada, the interior of British Columbia, and more extensive portions of the Prairies provinces, Ontario, and Québec. In these regions, March
SWE is expected to decrease during anomalously warm years. The portion of the snow cover with $T_{d}<-20^{\circ} \mathrm{C}$, which is largely unaffected by temperature variability (SospedraAlfonso and Merryfield, 2017) and encompasses areas of the Northwest Territories and most of Nunavut in present-day climate, is projected to recede to the Canadian Archipelago by mid-century.

Turning to projected changes in sea ice, Fig. 13 shows the observed record of September sea ice extent (sea ice concentration $>15 \%$ ) across Canadian marine regions, compared to the CMIP5 multi-model ensemble. While the observed and simulated trends are similar, only those years with strong observed negative departures from the long-term trend (e.g. 1998 and 2012) reach the mean simulated ice extent. During the historical record, the models have a large spread (gray histogram, right side of Fig. 13), with most models within the range of observations. After 2050, the large spread persists, but most models are $\sim 10 \%$ below the historical sea ice extent (yellow histogram, right side of Fig. 13).

The probability of sea-ice-free conditions by 2050 for regions of the Canadian Arctic calculated from the CMIP5 multi-model ensemble are shown in Fig. 14. SIC from each model realization is rescaled to account for differences in relative land and ocean fraction in a given region. For a given month, model, and ice area threshold, a particular region is considered sea-ice-free if more than $94 \%$ of its component grid cells have SIC below the ice area threshold for 5 out of the 6 years following 2050. The value of $94 \%$ is equivalent to the criterion established in Kirtman et al. (2013) to denote sea-ice-free conditions for the Arctic as a whole (less than $1 \times 10^{6} \mathrm{~km}^{2}$ of sea ice in the Arctic ocean). Probabilities are 


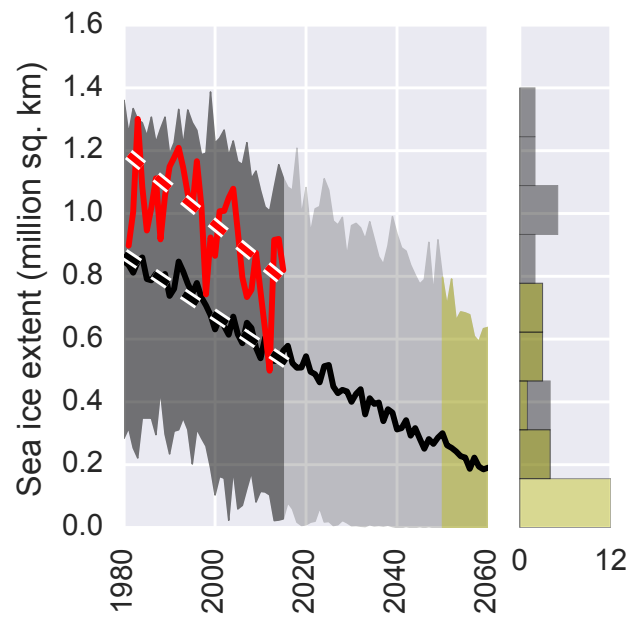

Figure 13. Observed (red line) September sea ice extent over Canadian marine regions (SIC > 0.15): CMIP5 multi-model mean (black line) and spread (shading). Histogram on the right shows the model distribution for 1980-2015 in black and for 2050-2060 in yellow.

calculated as the fraction of total realizations with ice-free conditions for a given region (see Laliberté et al., 2016, for a full description of the sea-ice-free probability methodology). Use of two ice area thresholds, 5 and $30 \%$, applied to each grid cell, indicate the sensitivity in timing to the definition of minimum ice area. Under a $5 \%$ ice area scenario, there is a greater than $50 \%$ probability that all Canadian regions will be sea-ice-free in September by the year 2050. Ice-free probabilities are similar for August, but lower for October and November. Hudson Bay, which is already largely icefree in August and September, has a high probability of being ice-free for 4 consecutive months. With a more relaxed threshold of $30 \%$ ice area, probabilities are (by definition) greater for all regions and months. By mid-century, Baffin Bay is projected to be ice-free for August through October, and 2 months of ice-free conditions in the Beaufort Sea and the CAA are a possibility.

\section{Key findings}

This assessment of observed historical changes in terrestrial snow cover and sea ice over Canada, together with projected changes to the middle of the 21 st century, has produced the following key findings.

\section{Historical datasets show the fraction of Canadian land and marine areas covered by snow and ice is decreasing}

Observations show decreased SIC in all seasons and decreased terrestrial SCF in fall (delayed snow cover onset) and spring (earlier snow melt). There is regional and seasonal variability in the direction and strength of the trends (for example, some increases in spring snow cover across bo- real western Canada) due to seasonal and spatial variability in surface temperature trends resulting from natural climate variability. There is evidence of decreasing annual maximum SWE (reflective of shallower snow depth) consistent with the study of Mudryk et al. (2015) and trends of annual maximum snow depth reported in Vincent et al. (2015). There is only regional evidence (western CAA) of increasing winter season snow accumulation and hence higher SWE across Arctic Canada. Summer season total ice cover is decreasing significantly across nearly all Canadian marine regions. MYI losses are greatest in the Beaufort Sea and the western CAA. In just 8 years, the rate of MYI loss nearly doubled over the 1968-2016 period compared to a previous assessment over 1968-2008. Sixty-year records of in situ landfast ice thickness show evidence of thinning ice in the CAA that was not evident in an earlier study by Brown and Cote (1992), which covered the late 1950s to 1989.

\section{Canadians should anticipate further reductions in snow and sea ice cover by the middle of the 21 st century}

Averaging projections across many climate model simulations provides evidence that SCF, SWEmax, and SIC will continue to decrease across Canadian land and marine areas through the middle of the 21 st century. However, this decrease need not be spatially uniform and regions of negligible decrease or even increase are possible in the near future due to climate variability competing with anthropogenic forcing at the decadal and multi-decadal timescale. For the highly populated regions of southern Canada, there is evidence of a shift in the primary control on inter-annual variability in snow cover from a regime dominated by precipitation to one dominated by surface temperature. While the thickest sea ice in the world will continue to be present in the CAA and along its northern coast, climate models suggest that Canadian Arctic marine regions which are currently ice covered could be sea-ice-free in the summer by 2050 .

\section{Discussion}

Snow cover is a defining characteristic of the Canadian landscape for a few months each winter along the southern margins of the country and up to 9 or 10 months each year in the high Arctic, evolving from nearly complete snow cover over the entire country in the winter to a near total loss of snow cover by the summer. Highly reflective snow cover acts to cool the climate system, effectively insulates the underlying soil, and stores and redistributes water in solid form through the accumulation season before spring melt. Sea ice insulates the ocean from the atmosphere, provides an essential habitat for northern mammals, influences navigation and access to the north, and is of high importance to the traditional lifestyle of northern communities. This assessment of observed and projected changes in seasonal terrestrial snow and sea ice is 

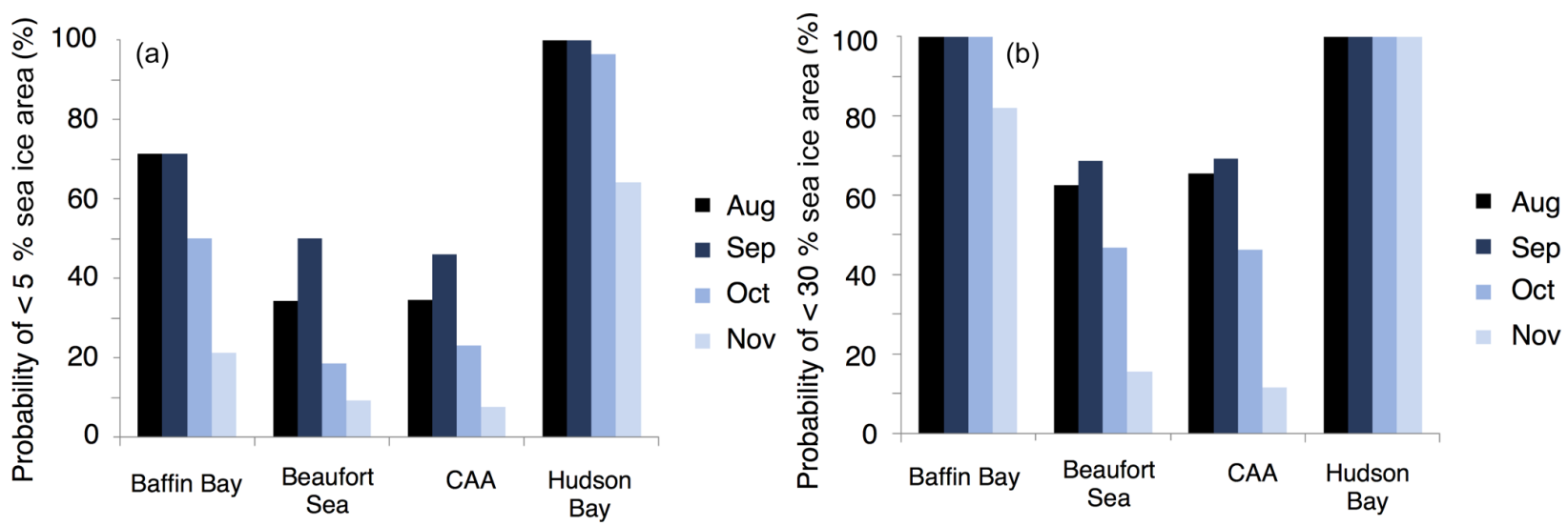

Figure 14. Probability of sea-ice-free conditions by 2050 from the CMIP5 multi-model mean using a $5 \%$ (a) and $30 \%$ (b) sea ice area threshold.

focused on Canadian territory, but a number of cross-cutting issues with broader implications for understanding interactions between the cryosphere and climate system were identified through this analysis:

1. The majority of previous assessments of snow cover trends (i.e. Derksen and Brown, 2012; HernandezHenriquez et al., 2015; Derksen et al., 2016; Kunkel et al., 2016) were based on the NOAA snow chart climate data record (NOAA-CDR; Estilow et al., 2015) selected on the basis of the longest available record. The reliance on individual datasets such as the NOAA-CDR, however, makes trends prone to uncertainty due to the inherent uncertainties in an individual dataset (for instance, see Brown and Derksen, 2013, and Mudryk et al., 2017, for issues related to the NOAA-CDR). It is clear that consideration of multiple datasets either as a means of showing the range of trends from individual datasets (Mudryk et al., 2017), for calculating confidence intervals around an individual dataset (Brown and Robinson, 2011), or to benchmark other datasets (Brown et al., 2010; Hori et al., 2017) is a more robust approach. However, in this case, we acknowledge that the availability and use of multiple datasets came at the sacrifice of time series length (the NOAA record extends back to 1967 , whereas passive microwave satellite data and reanalyses such as ERA-Interim only begin in 1979).

2. Alpine snow poses a unique challenge to trend analysis because the coarse spatial resolution of gridded products used for climate analysis cannot resolve the high degree of spatial variability (driven by land cover variability and steep topographic gradients) in alpine regions. Wrzesien et al. (2018) have shown that blended gridded products like the one used in this analysis may significantly underestimate SWE in alpine regions. Because alpine show trends vary with elevation in a complex manner (Sospedra-Alfonso et al., 2015; Hamlet et al., 2005), trends from coarse-resolution products like the one used in our analysis are comparatively more uncertain in alpine areas compared to other regions. It is imperative that we address and improve our ability to characterize variability and change in alpine snow because it is these regions that are both extremely sensitive to climate-induced changes in snow accumulation (i.e. elevation-dependent changes in rainfall versus snowfall ratios) and impactful with respect to water resources (Fyfe et al., 2017; Berg and Hall, 2017; Sospedra-Alfonso et al., 2015; Scalzitti et al., 2016).

3. Changes in sea ice are driven by warming temperatures, but also by changes in atmospheric circulation. The Beaufort Sea was once a region where ice would thicken and age before being transported to the Chukchi Sea and re-circulated in the Arctic (Tucker et al., 2001; Rigor et al., 2002) but now the region has become a considerable contributor to the Arctic's MYI loss (Kwok and Cunningham, 2010; Maslanik et al., 2011; Krishfield et al., 2014; Galley et al., 2016). Ice is still being sequestered from the Canadian Basin and transported through the Beaufort Sea during the summer months but the ice is now younger and thinner and unable survive the melt season en route to the Chukchi Sea (Howell et al., 2016a). The CAA was also a region with historically heavy MYI conditions present throughout the melt season but ice conditions have become lighter in recent years (see Fig. 7b). The replenishment of CAA MYI via first-year ice aging and MYI inflow from the Arctic Ocean has decreased in recent years because of increased temperature and changes in atmospheric circulation (Howell et al., 2015).

4. There is a strong association between the magnitude of warming and snow and ice loss both in observational datasets and climate model simulations, with projected declines in snow and sea ice cover proportional to 
the amount of future warming (Thackeray et al., 2016; Mudryk et al., 2017; Notz and Stroeve, 2016). The multi-model mean projections indicate decreasing snow and ice cover because the multi-model mean projects a warmer climate by mid-century. Within this multimodel mean, however, individual climate model realizations contain regions and seasons with cooling trends (see Mudryk et al., 2014). It is important to remember, therefore, that we live in a single climate realization, while models produce dozens of potential realizations of a future climate. The multi-model mean warming trend (with associated reductions in snow and ice cover) is indicative of a high likelihood of a warmer future, but there will be decadal-scale natural variability, particularly at regional scales, projected onto this overall trend.

The objective of this paper was to provide a physical climate assessment of observed and projected changes in snow and ice across Canada. While not the focus of this study, these changes will have profound impacts on terrestrial and marine ecosystems and on many sectors of the Canadian economy. This includes risks related to freshwater supply from snow (Sturm et al., 2017) and other impacts of changing snow on the Canadian landscape and economy (Sturm et al., 2016). Accurately estimating dates of summer sea-icefree conditions in Canadian regions (Laliberté et al. (2016) has important implications for climate studies as well as for determining impact and mitigation strategies. For example, the decreases in MYI within the Beaufort Sea and the CAA illustrated in Fig. 6 were found to be statistically linked to an increase in shipping activity, pointing out the potential implications of continued sea ice declines in these regions (Pizzolato et al., 2016).

Data availability. Environment and Climate Change Canada's Canadian Centre for Climate Modelling and Analysis executed and made publicly available the CanESM2-LE simulations used in this study. Eric Brun provided data from the Crocus snowpack model, and Ross Brown provided the Brown dataset. These data are available from the paper's authors upon request. The remaining datasets are available for download via the links and references provided in Sect. 2.1 and 2.2.

Competing interests. The authors declare that they have no conflict of interest.

Acknowledgements. This work represents "Deliverable 2" of the CanSISE Network. CanSISE was funded under the auspices of the Natural Science and Engineering Research Council of Canada's Climate Change and Atmospheric Research Program, with additional support provided by Environment and Climate Change Canada, the Pacific Climate Impacts Consortium, and the University of Toronto. The original manuscript was improved thanks to comments from Christoph Marty and one anonymous reviewer.

Edited by: Martin Schneebeli

Reviewed by: Christoph Marty and one anonymous referee

\section{References}

Agnew, T. and Howell, S.: The use of operational ice charts for evaluating passive microwave ice concentration data, Atmos.-Ocean, 41, 317-331, https://doi.org/10.3137/ao.410405, 2003.

Archambault, M., Audet, A., and Morin, J.: The 2002-2003 Economic Analysis of the Québec Ski Industry, Association of Québec Ski Areas, Anjou, Québec, 2003.

Arora, V. K., Scinocca, J. F., Boer, G. J., Christian, J. R., Denman, K. L., Flato, G. M., Kharin, V. V., Lee, W. G., and Merryfield, W. J.: Carbon emission limits required to satisfy future representative concentration pathways of greenhouse gases, Geophys. Res. Lett., 38, 3-8, https://doi.org/10.1029/2010GL046270, 2011.

Babb, D. G., Galley, R. J., Barber, D. G., and Rysgaard, S.: Physical processes contributing to an ice free Beaufort Sea during September 2012, J. Geophys. Res., 121, 267-283, https://doi.org/10.1002/2015JC010756, 2016.

Barnes, E.: Revisiting the evidence linking Arctic amplification to extreme weather in midlatitudes, Geophys. Res. Lett., 40, 47344739, https://doi.org/10.1002/grl.50880, 2013.

Barnett, T., Adam, J., and Lettenmaier, D.: Potential impacts of a warming climate on water availability in snow-dominated regions, Nature, 438, 303-309, https://doi.org/10.1038/nature04141, 2005.

Berg, N. and Hall, A.: Anthropogenic warming impacts on California snowpack during drought, Geophys. Res. Lett., 44, 25112518, https://doi.org/10.1002/2016GL072104, 2017.

Bokhorst, S., Pedersen, S. H., Brucker, L. Anisimov, O., Bjerke, J. W., Brown, R. D., Ehrich, D., Essery, R. L. H., Heilig, A., Ingvander, A., Johansson, C., Johansson, M., Jónsdóttir, I. S., Inga, N., Luojus, K., Macelloni, G., Mariash, H., McLennan, D., Rosqvist, G. N., Sato, A., Savela, H., Schneebeli, M., Sokolov, A., Sokratov, S. A., Terzago, A., Vikhamar-Schuler, D., Williamson, S., Qiu, Y., and Callaghan, T. V.: Changing Arctic snow cover: A review of recent developments and assessment of future needs for observations, modelling, and impacts, Ambio, 45, 516, https://doi.org/10.1007/s13280-016-0770-0, 2016.

Brasnett, B.: A global analysis of snow depth for numerical weather prediction, J. Appl. Meteorol., 38, 726-740, 1999.

Brown, R. and Cote, P.: Interannual variability of landfast ice thickness in the Canadian high arctic, 1950-89, Arctic, 45, 273-284, 1992.

Brown, R. and Derksen, C.: Is Eurasian October snow cover extent increasing?, Environ. Res. Lett., 8, 024006, https://doi.org/10.1088/1748-9326/8/2/024006, 2013.

Brown, R. and Mote, P.: The response of Northern Hemisphere snow cover to a changing climate, J. Climate, 22, 2124-2145, 2009.

Brown, R., Brasnett, B., and Robinson, D.: Gridded North American monthly snow depth and snow water equivalent for GCM evaluation, Atmos.-Ocean, 41, 1-14, 2003. 
Brown, R., Derksen, C., and Wang, L.: A multi-dataset analysis of variability and change in Arctic spring snow cover extent, 1967-2008, J. Geophys. Res., 115, D16111, https://doi.org/10.1029/2010JD013975, 2010.

Brown, R., Schuler, D., Bulygina, O., Derksen, C., Luojus, K., Mudryk, L., Wang, L., and Yang, D.: Arctic terrestrial snow, in: Snow, Water, Ice and Permafrost in the Arctic (SWIPA), Arctic Monitoring and Assessment Program (AMAP), Oslo, Norway, 25-64, 2017.

Brown, R. D. and Braaten, R. O.: Spatial and temporal variability of Canadian monthly snow depths, 1946-1995, Atmos.-Ocean, 36, 37-45, 1998.

Brown, R. D. and Robinson, D. A.: Northern Hemisphere spring snow cover variability and change over 1922-2010 including an assessment of uncertainty, The Cryosphere, 5, 219-229, https://doi.org/10.5194/tc-5-219-2011, 2011.

Brun, E., Vionnet, V., Boone, A., Decharme, B., Peings, Y., Valette, R., Karbou, F., and Morin, S.: Simulation of Northern Eurasian local snow depth, mass, and density using a detailed snowpack model and meteorological reanalyses, J. Hydrometeorol., 14, 203-219, https://doi.org/10.1175/JHM-D-12-012.1, 2013.

Canadian Ice Service: Regional charts: History, accuracy, and caveats, Arch. Doc. Ser. 1, Ottawa., available at: http://ice.ec. gc.ca/IA_DOC/cisads_no_001_e.pdf (last access: 25 July 2017), 2007.

Cohen, J., Barlow, M., Kushner, P. J., and Saito, K.: Stratosphere-Troposphere Coupling and Links with Eurasian Land Surface Variability, J. Climate, 20, 5335-5343, https://doi.org/10.1175/2007JCLI1725.1, 2007.

Conlan, M. and Jamieson, B.: A decision support tool for dry persistent deep slab avalanches for the transitional snow climate of western Canada, Cold Reg. Sci. Technol., 144, 16-27, https://doi.org/10.1016/j.coldregions.2017.06.013, 2017.

Dee, D. P., Uppala, S. M., Simmons, A. J., Berrisford, P., Poli, P., Kobayashi, S., Andrae, U., Balmaseda, M. A., Balsamo, G., Bauer, P., Bechtold, P., Beljaars, A. C. M., van de Berg, L., Bidlot, J., Bormann, N., Delsol, C., Dragani, R., Fuentes, M., Geer, A. J., Haimberger, L., Healy, S. B., Hersbach, H., Hólm, E. V., Isaksen, L., Kållberg, P., Köhler, M., Matricardi, M., McNally, A. P., Monge-Sanz, B. M., Morcrette, J.-J., Park, B.-K., Peubey, C., de Rosnay, P., Tavolato, C., Thépaut, J.-N., and Vitart, F.: The ERA-Interim reanalysis: configuration and performance of the data assimilation system, Q. J. Roy. Meteor. Soc., 137, 553-597, https://doi.org/10.1002/qj.828, 2011.

Derksen, C. and Brown, R.: Spring snow cover extent reductions in the 2008-2012 period exceeding climate model projections, Geophys. Res. Lett., 39, L19504, https://doi.org/10.1029/2012GL053387, 2012.

Derksen, C., Smith, S. L., Sharp, M., Brown, L., Howell, S., Copland, L., Mueller, D. R., Gauthier, Y., Fletcher, C. G., Tivy, A., Bernier, M., Bourgeois, J., Brown, R., Burn, C. R., Duguay, C., Kushner, P., Langlois, A., Lewkowicz, A. G., Royer, A., and Walker, A.: Variability and change in the Canadian cryosphere, Climatic Change, 115, 59, https://doi.org/10.1007/s10584-0120470-0, 2012.

Derksen, C., Brown, R., Mudryk, L., and Luojus, K.: Terrestrial Snow (Arctic), in: State of the Climate in 2015, B. Am. Meteorol. Soc., 97, 145-147, 2016.
ERA-Interim: ERA-Interim is a global atmospheric reanalysis from 1979, continuously updated in real time, available at: http:// www.ecmwf.int/en/research/climate-reanalysis/era-interim, last access: 11 April 2017.

Estilow, T. W., Young, A. H., and Robinson, D. A.: A long-term Northern Hemisphere snow cover extent data record for climate studies and monitoring, Earth Syst. Sci. Data, 7, 137-142, https://doi.org/10.5194/essd-7-137-2015, 2015.

Eyring, V., Bony, S., Meehl, G. A., Senior, C. A., Stevens, B., Stouffer, R. J., and Taylor, K. E.: Overview of the Coupled Model Intercomparison Project Phase 6 (CMIP6) experimental design and organization, Geosci. Model Dev., 9, 1937-1958, https://doi.org/10.5194/gmd-9-1937-2016, 2016.

Flanner, M., Shell, K., Barlage, M., Perovich, D., and Tschudi, M.: Radiative forcing and albedo feedback from the Northern Hemisphere cryosphere between 1979 and 2008, Nature Geosci., 4, 151-155, https://doi.org/10.1038/ngeo1062, 2011.

Francis, J. and Vavrus, S.: Evidence linking Arctic amplification to extreme weather in mid-latitudes, Geophys. Res. Lett., 39, L06801, https://doi.org/10.1029/2012GL051000, 2012.

Francis, J. and Vavrus, S.: Evidence for a wavier jet stream in response to rapid Arctic warming, Environ. Res. Lett., 10, 014005, https://doi.org/10.1088/1748-9326/10/1/014005, 2015.

Francis, J., Vavrus, S., and Cohen, J.: Amplified Arctic warming and mid-latitude weather: new perspectives on emerging connections, Wires. Clim. Change, 8, e474, https://doi.org/10.1002/wcc.474, 2017.

Fyfe, J., Derksen, C., Mudryk, L., Flato, G,. Santer, B., Swart, N., Molotch, N., Zhang, X., Wan, H. Arora, V., Scinocca, J., and Jiao, Y: Large near-term projected snowpack loss over the western United States, Nature Comms., 8, 14996, https://doi.org/10.1038/NCOMMS14996, 2017.

Galley, R. J., Babb, D., Ogi, M., Else, B. G. T., Geilfus, N.-X., Crabeck, O., Barber, D. G., and Rysgaard, S.: Replacement of multiyear sea ice and changes in the open water season duration in the Beaufort Sea since 2004, J. Geophys. Res.-Oceans, 121, 1806-1823, https://doi.org/10.1002/2015JC011583, 2016.

Ganji, A., Sushama, L., Verseghy, D., and Harvey, R.: On improving cold region hydrological processes in the Canadian Land Surface Scheme, Theor. Appl. Climatol., 127, 45-59, 2017.

Gelaro, R., McCarty, W., Suárez, M. J., Todling, R., Molod, A., Takacs, L., Randles, C. A., Darmenov, A., Bosilovich, M. G., Reichle, R., Wargan, K., Coy, L., Cullather, R., Draper, C., Akella, S., Buchard, V., Conaty, A., da Silva, A. M., Gu, W., Kim, G., Koster, R., Lucchesi, R., Merkova, D., Nielsen, J. E., Partyka, G., Pawson, S., Putman, W., Rienecker, M., Schubert, S. D., Sienkiewicz, M., and Zhao, B.: The Modern-Era Retrospective Analysis for Research and Applications, Version 2 (MERRA-2), J. Climate, 30, 5419-5454, https://doi.org/10.1175/JCLI-D-160758.1, 2017.

Global Modeling and Assimilation Office: MERRA2 tavg1_2d_lnd_Nx: 2d, 1-Hourly, Time-Averaged, Single-Level, Assimilation, Land Surface Diagnostics V5.12.4, Greenbelt, MD, USA, Goddard Earth Sciences Data and Information Services Center (GES DISC), https://doi.org/10.5067/RKPHT8KC1Y1T, last access: 13 July 2016.

Global Modeling and Assimilation Office: MERRA-1 tavgM_2d_slv_Nx: MERRA 2D IAU Diagnostic, Single Level 
Meteorology, Monthly Mean V5.2.0, Greenbelt, MD, USA, Goddard Earth Sciences Data and Information Services Center (GES DISC), https://doi.org/10.5067/W3UEUC5V7M9M, last access: 11 April 2017a.

Global Modeling and Assimilation Office: MERRA-2 tavgM_2d_slv_Nx: 2d, Monthly mean, Time-Averaged, Single-Level, Assimilation, Single-Level Diagnostics V5.12.4, Greenbelt, MD, USA, Goddard Earth Sciences Data and Information Services Center (GES DISC), https://doi.org/10.5067/AP1B0BA5PD2K, last access: 11 April 2017b.

Gouttevin, I., Menegoz, M., Dominé, F., Krinner, G., Koven, C., Ciais, P., Tarnocai, C., and Boike, J.: How the insulating properties of snow affect soil carbon distribution in the continental pan-Arctic area, J. Geophys. Res., 117, G02020, https://doi.org/10.1029/2011JG001916, 2012.

Haas, C. and Howell, S. E. L.: Ice thickness in the Northwest Passage, Geophys. Res. Lett., 42, 7673-7680, https://doi.org/10.1002/2015GL065704, 2015.

Haas, C., Hendricks, S., Eicken, H., and Herber, A.: Synoptic airborne thickness surveys reveal state of Arctic sea ice cover, Geophys. Res. Lett., 37, L09501, https://doi.org/10.1029/2010GL042652, 2010.

Hamlet, A., Mote, P., Clark, M., and Lettenmeier, D.: Effects of temperature and precipitation variability on snowpack trends in the western United States, J. Climate, 18, 4545-4561, 2005.

Hanewinkel, M., Breidenbach, J. Neeff, T., and Kublin, E.: Seventyseven years of natural disturbances in a mountain forest area the influence of storm, snow, and insect damage analysed with a long-term time series, Can. J. Forest Res., 38, 2249-2261, 2008.

Hawkins, E. and Sutton, R.: The Potential to Narrow Uncertainty in Regional Climate Predictions, B. Am. Meteorol. Soc., 90, 10951107, https://doi.org/10.1175/2009BAMS2607.1, 2009.

Hawkins, E. and Sutton, R.: The potential to narrow uncertainty in projections of regional precipitation change, Clim. Dyn., 37, 407-481, https://doi.org/10.1007/s00382-010-0810-6, 2011.

Hernández-Henríquez, M., Déry, S., and Derksen, C.: Polar amplification and elevation-dependence in trends of Northern Hemisphere snow cover extent, 1971-2014, Environ. Res. Lett., 10, 044010, https://doi.org/10.1088/1748-9326/10/4/044010, 2015.

Hochheim, K. P. and Barber, D. G.: An update on the ice climatology of the Hudson Bay system, Arct. Antarct. Alp. Res., 46, 66-83, https://doi.org/10.1657/1938-4246-46.1.66, 2014.

Hong, H. P. and Ye, W. : Analysis of extreme ground snow loads for Canada using snow depth records, Nat. Hazards, 73, 355-371, 2014.

Hori, M., Sugiura, K., Kobayashi, K., Aoki, T., Tanikawa, T., Kuchiki, K., Niwano, M., and Enomoto, H.: A 38year (1978-2015) Northern Hemisphere daily snow cover extent product derived using consistent objective criteria from satellite-borne optical sensors, Proc. Spie., 191, 402-418, https://doi.org/10.1016/j.rse.2017.01.023, 2017.

Howell, S. E. L., Duguay, C. R., and Markus, T.: Sea ice conditions and melt season duration variability within the Canadian Arctic Archipelago: 1979-2008, Geophys. Res. Lett., 36, L10502, https://doi.org/10.1029/2009GL037681, 2009.

Howell, S. E. L., Wohlleben, T., Dabboor, M., Derksen, C., Komarov, A., and Pizzolato, L.: Recent changes in the exchange of sea ice between the Arctic Ocean and the Cana- dian Arctic Archipelago, J. Geophys. Res., 118, 3595-3607, https://doi.org/10.1002/jgrc.20265, 2013a.

Howell, S. E. L., Wohlleben, T., Komarov, A., Pizzolato, L., and Derksen, C.: Recent extreme light sea ice years in the Canadian Arctic Archipelago: 2011 and 2012 eclipse 1998 and 2007, The Cryosphere, 7, 1753-1768, https://doi.org/10.5194/tc7-1753-2013, 2013b.

Howell, S. E. L., Derksen, C.,Pizzolato, L., and Brady, M.: Multiyear ice replenishment in the Canadian Arctic Archipelago: 1997-2013, J. Geophys. Res., 120, 1623-1637, https://doi.org/10.1002/2015JC010696, 2015.

Howell, S. E. L., Brady, M., Derksen, C., and Kelly, R. E. J.: Recent changes in sea ice area flux through the Beaufort Sea during the summer, J. Geophys. Res.-Oceans, 121, 2659-2672, https://doi.org/10.1002/2015JC011464, 2016a.

Howell, S. E. L., Laliberté, F., Kwok, R., Derksen, C., and King, J.: Landfast ice thickness in the Canadian Arctic Archipelago from observations and models, The Cryosphere, 10, 1463-1475, https://doi.org/10.5194/tc-10-1463-2016, 2016 b.

Japan Meteorological Agency (JMA): Japanese 55-year Reanalysis (JRA-55), available at: http://jra.kishou.go.jp/JRA-55/index_en. html, last access: 11 April 2017.

Japan Meteorological Agency (JMA) and the Central Research Institute of Electric Power Industry (CRIEPI): Japanese 25year ReAnalysis (JRA-25), available at: http://jra.kishou.go.jp/ JRA-25/index_en.html, last access: 11 April 2017.

Kang, D. H., Shi, X., Gao, H., and Déry, S. J.: On the changing contribution of snow to the hydrology of the Fraser River Basin, Canada, J. Hydrometeorol., 1, 1344-1365, 2014.

Kirtman, B., Power, S. B., Adedoyin, J. A., Boer, G. J., Bojariu, R., Camilloni, I., Doblas-Reyes, F. J., Fiore, A. M., Kimoto, M., Meehl, G. A., Prather, M., Sarr, A., Schär, C., Sutton, R., van Oldenborgh, G. J., Vecchi, G., and Wang, H. J.: Near-term Climate Change: Projections and Predictability, in: Climate Change 2013: The Physical Science Basis, Contribution of Working Group I to the Fifth Assessment Report of the Intergovernmental Panel on Climate Change, edited by: Stocker, T. F., Qin, D., Plattner, G.-K., Tignor, M., Allen, S. K., Boschung, J., Nauels, A., Xia, Y., Bex, V., and Midgley, P. M., Cambridge University Press, Cambridge, UK and New York, NY, USA, 2013.

Kobayashi, S., Ota, Y., Harada, Y., Ebita, A., Moriya, M., Onoda, H., Onogi, K., Kamahori, H., Kobayashi, C., Endo, H., Miyaoka, K., and Takahashi, K.: The JRA-55 Reanalysis: General specifications and basic characteristics, J. Meteor. Soc. Japan, 93, 5-48, https://doi.org/10.2151/jmsj.2015-001, 2015.

Krishfield, R. A., Proshutinsky, A., Tateyama, K., Williams, W. J., Carmack, E. C., McLaughlin, F. A., and Timmermans, M.-L.: Deterioration of perennial sea ice in the Beaufort Gyre from 2003 to 2012 and its impact on the oceanic freshwater cycle, J. Geophys. Res., 119, 1271-1305, https://doi.org/10.1002/2013JC008999, 2014.

Kunkel, K., Robinson, D., Champion, S., Yin, X., Estilow, T., and Frankson, R.: Trends and Extremes in Northern Hemisphere Snow Characteristics, Curr. Clim. Change Rep., 2, 65-73, https://doi.org/10.1007/s40641-016-0036-8, 2016.

Kushner, P. J., Mudryk, L. R., Merryfield, W., Ambadan, J. T., Berg, A., Bichet, A., Brown, R., Derksen, C., Déry, S. J., Dirkson, A., Flato, G., Fletcher, C. G., Fyfe, J. C., Gillett, N., Haas, C., Howell, S., Laliberté, F., McCusker, K., Sigmond, M., Sospreda- 
Alfonso, R., Tandon, N. F., Thackeray, C., Tremblay, B., and Zwiers, F. W.: Canadian snow and sea ice: assessment of snow, sea ice, and related climate processes in Canada's Earth system model and climate-prediction system, The Cryosphere, 12, 1137-1156, https://doi.org/10.5194/tc-12-1137-2018, 2018.

Kwok, R. and Cunningham, G. F.: Contribution of melt in the Beaufort Sea to the decline in Arctic multiyear sea ice coverage: 1993-2009, Geophys. Res. Lett., 37, L20501, https://doi.org/10.1029/2010GL044678, 2010.

Kwok, R. and Cunningham, G. F.: Variability of Arctic sea ice thickness and volume from CryoSat-2, Philos. T. Roy. Soc. A., 373, 20140157, https://doi.org/10.1098/rsta.2014.0157, 2015.

Kwok, R. and Rothrock, D. A.: Decline in Arctic sea ice thickness from submarine and ICESat records: 1958-2008, Geophys. Res. Lett., 36, L15501, https://doi.org/10.1029/2009GL039035, 2009.

Laliberté, F., Howell, S. E. L., and Kushner, P. J.: Regional variability of a projected sea ice-free Arctic during the summer months, Geophys. Res. Lett., 43, 256-263 https://doi.org/10.1002/2015GL066855, 2016.

Laxon S. W., Giles, K. A., Ridout, A. L., Wingham, D. J., Willatt, R., Cullen, R., Kwok, R., Schweiger, A., Zhang, J., Haas, C., Hendricks, S. Krishfield, R., Kurtz, N., Farrell, S., and Davidson, M.: CryoSat-2 estimates of Arctic sea ice thickness and volume, Geophys. Res. Lett., 40, 732-737, https://doi.org/10.1002/grl.50193, 2013.

Lindsay, R., Haas, C., Hendricks, A., Hunkeler, P., Kurtz, N., Paden, J., Panzer, B., Sonntag, J., Yungel, J., and Zhang, J.: Seasonal forecasts of Arctic sea ice initialized with observations of ice thickness, Geophys. Res. Lett., 39, L21502, https://doi.org/10.1029/2012GL053576, 2012.

Luus, K. A., Kelly, R. E. J., Lin, J. C., Humphreys, E. R., Lafleur P. M., and Oechel, W. C.: Modeling the influence of snow cover on low Arctic net ecosystem exchange, Env. Res. Lett., 8, 035045, https://doi.org/10.1088/1748-9326/8/3/035045, 2013.

Maslanik, J., Stroeve, J., Fowler, C., and Emery, W.: Distribution and trends in Arctic sea ice age through spring 2011, Geophys. Res. Lett., 38, L13502, https://doi.org/10.1029/2011GL047735, 2011.

Mekis, É. and Vincent, L. A.: An overview of the second generation adjusted daily precipitation dataset for trend analysis in Canada, Atmos.-Ocean, 49, 163-177, https://doi.org/10.1080/07055900.2011.583910, 2011.

Milewska, E., Hopkinson, R. F., and Niitsoo, A.: Evaluation of georeferenced grids of 1961-1990 Canadian temperature and precipitation normals, Atmos.-Ocean, 43, 49-75, 2005.

Mudryk, L., Kushner, P., and Derksen, C.: Interpreting observed Northern Hemisphere snow trends with large ensembles of climate simulations, Clim. Dyn., 43, 345-359, https://doi.org/10.1007/s00382-013-1954-y, 2014.

Mudryk, L., Derksen, C., Kushner, P., and Brown, R.: Characterization of Northern Hemisphere snow water equivalent datasets, 1981-2010, J. Climate, 28, 8037-8051, 2015.

Mudryk, L. R., Kushner, P. J., Derksen, C., and Thackeray, C.: Snow cover response to temperature in observational and climate model ensembles, Geophys. Res. Lett., 44, 919-926, https://doi.org/10.1002/2016GL071789, 2017.

NOAA/National Weather Service: The Climate Forecast System Reanalysis [1979-2010], available at: http://cfs.ncep.noaa.gov/ cfsr/, last access: 11 April 2017.
Notz, D. and Stroeve, J.: Observed Arctic sea-ice loss directly follows anthropogenic $\mathrm{CO}_{2}$ emission, Science, 354, 747-750, https://doi.org/10.1126/science.aag2345, 2016.

Onogi, K., Tsutsui, J., Koide, H., Sakamoto, M., Kobayashi, S. Hatsushika, H., Matsumoto, T., Yamazaki, N., Kamahori, H., Takahashi, K., Kadokura, A., Wada, K., Kato, K., Oyama, R., Ose, T., Mannoji, N., and Taira, R.: The JRA-25 Reanalysis, J. Meteor. Soc. Japan, 85, 369-432, 2007.

Parkinson, C. L.: Spatially mapped reductions in the length of the Arctic sea ice season, Geophys. Res. Lett., 41, 4316-4322, https://doi.org/10.1002/2014GL060434, 2014.

Peters, G. P., Andrew, R. M., Boden, T., Canadell, J. G., Ciais, P., Quéré, C. L., Marland, G., Raupach, M. R., and Wilson, C.: The challenge to keep global warming below $2{ }^{\circ} \mathrm{C}$, Nat. Clim. Chang., 3, 4-6, https://doi.org/10.1038/nclimate1783, 2012.

Pithan, F. and Mauritsen, T.: Arctic amplification dominated by temperature feedbacks in contemporary climate models, Nat. Geosci., 7, 181-184, https://doi.org/10.1038/ngeo2071, 2014.

Pizzolato, L., Howell, S. E. L., Dawson, J., Laliberté, F., and Copland, L.: The influence of declining sea ice on shipping activity in the Canadian Arctic, Geophys. Res. Lett., 43, 12146-12154, https://doi.org/10.1002/2016GL071489, 2016.

Raisanen, J.: Warmer climate: less or more snow?, Clim. Dyn., 30, 307-319, 2008.

Rapaic, M., Brown, R., Markovic, M., and Chaumont, D.: An evaluation of temperature and precipitation surface-based and reanalysis datasets for the Canadian Arctic, 1950-2010, Atmos.-Ocean, 53, 283-303, https://doi.org/10.1080/07055900.2015.1045825, 2015.

Richter-Menge, J. A. and Farrell S. L.: Arctic sea ice conditions in spring 2009-2013 prior to melt, Geophys. Res. Lett., 40, 58885893, https://doi.org/10.1002/2013GL058011, 2013.

Rienecker, M. M., Suarez, M. J., Gelaro, R., Todling, R., Bacmeister, J., Liu, E., Bosilovich, M. G., Schubert, S. D., Takacs, L., Kim, G., Bloom, S., Chen, J., Collins, D., Conaty, A., da Silva, A., Gu, W., Joiner, J., Koster, R. D., Lucchesi, R., Molod, A., Owens, T., Pawson, S., Pegion, P., Redder, C. R., Reichle, R., Robertson, F. R., Ruddick, A. G., Sienkiewicz, M., and Woollen, J.: MERRA: NASA's Modern-Era Retrospective Analysis for Research and Applications, J. Climate, 24, 3624-3648, https://doi.org/10.1175/JCLI-D-11-00015.1, 2011

Rigor, I. G., Wallace, J. M., and Colony, R. L.: Response of sea ice to the Arctic oscillation, J. Climate, 15, 2648-2663, https://doi.org/10.1175/15200442(2002)015<2648:ROSITT>2.0.CO;2, 2002.

Saha, S., Moorthi, S., Pan, H., Wu, X., Wang, J., Nadiga, A., Tripp, P., Kistler, R., Woollen, J., Behringer, D., Liu, H., Stokes, D., Grumbine, R., Gayno, G., Wang, J., Hou, Y., Chuang, H., Juang, H.H., Sela, J., Iredell, M., Treadon, R., Kleist, D., Van Delst, P., Keyser, D., Derber, J., Ek, M., Meng, J., Wei, H., Yang, R., Lord, S., van den Dool, H., Kumar, A., Wang, W., Long, C., Chelliah, M., Xue, Y., Huang, B., Schemm, J., Ebisuzaki, W., Lin, R., Xie, P., Chen, M., Zhou, S., Higgins, W., Zou, C., Liu, Q., Chen, Y., Han, Y., Cucurull, L., Reynolds, R.W., Rutledge, G., and Goldberg, M.: The NCEP Climate Forecast System Reanalysis, B. Am. Meteorol. Soc., 91, 1015-1058, https://doi.org/10.1175/2010BAMS3001.1, 2010.

Scaife, A. A., Arribas, A., Blockley, E., Brookshaw, A., Clark, R. T., Dunstone, N., Eade, R., Fereday, D., Folland, C. K., Gordon, 
M., Hermanson, L., Knight, J. R., Lea, D. J., MacLachlan, C., Maidens, A., Martin, M., Peterson, A. K., Smith, D., Vellinga, M., Wallace, E., Waters, J., and Williams, A.: Skillful long-range prediction of European and North American winters, Geophys. Res. Lett., 41, 2514-2519, doi:10.1002/2014GL059637, 2014.

Scalzitti, J., Strong, C., and Kochanski, A.: Climate change impact on the roles of temperature and precipitation in western U.S. snowpack variability, Geophys. Res. Lett., 43, 5361—5369, 2016.

Scott, D., McBoyle, G., and Minogue, A.: Climate change and Québec's ski industry, Global Environmental Change, 17, 181190, 2007.

Screen, J., Deser, C., and Sun, L.: Reduced risk of North American cold extremes due to continued Arctic sea ice loss, B. Am. Meteorol. Soc., 96, 1489-1503 https://doi.org/10.1175/BAMSD-14-00185.1, 2015.

Serreze, M., Barrett, A., Slater, A., Steele, M., Zhang, J., and Trenberth, K.: The large-scale energy budget of the Arctic, J. Geophys. Res., 112, D11122, https://doi.org/10.1029/2006JD008230, 2007.

Serreze, M. C., Barrett, A. P., Stroeve, J. C., Kindig, D. N., and Holland, M. M.: The emergence of surface-based Arctic amplification, The Cryosphere, 3, 11-19, https://doi.org/10.5194/tc-311-2009, 2009.

Sigmond, M., Fyfe, J. C., Flato, G. M., Kharin, V. V., and Merryfield, W. J.: Seasonal forecast skill of Arctic sea ice area in a dynamical forecast system, Geophys. Res. Lett., 40, 529-534, https://doi.org/10.1002/grl.50129, 2013.

Smith, K. L., Fletcher, C. G., and Kushner, P. J.: The Role of Linear Interference in the Annular Mode Response to Extratropical Surface Forcing, J. Climate, 23, 6036-6050, https://doi.org/10.1175/2010JCLI3606.1, 2010.

Sospedra-Alfonso, R. and Merryfield, W. J.: Influences of Temperature and Precipitation on Historical and Future Snowpack Variability over the Northern Hemisphere in the Second Generation Canadian Earth System Model, J. Climate, 30, 4633-4656, https://doi.org/10.1175/JCLI-D-16-0612.1, 2017.

Sospedra-Alfonso R., Melton J., and Merryfield, W.: Effects of temperature and precipitation on snowpack variability in the central Rocky Mountains as a function of elevation, Geophys. Res. Lett., 42, 4429-4438, 2015.

Stroeve, J. C., Markus, T., Boisvert, L., Miller, J., and Barrett, A.: Changes in Arctic melt season and implications for sea ice loss, Geophys. Res. Lett., 41, 1216-1225, https://doi.org/10.1002/2013GL058951, 2014.

Sturm, M., Goldstein, M., Huntington, H., and Douglas, T.: Using an option pricing approach to evaluate strategic decisions in a rapidly changing climate: Black-Scholes and climate change, Clim. Change, https://doi.org/10.1007/s10584016-1860-5, 2016.

Sturm, M., Goldstein, M. A., and Parr, C.: Water and life from snow: A trillion dollar science question, Water Resour. Res., 53, 35343544, https://doi.org/10.1002/2017WR020840, 2017.

Swart, N. C., Fyfe, J. C., Hawkins, E., Kay, J. E., and Jahn, A.: Influence of internal variability on Arctic sea-ice trends, Nat. Clim. Change, 5, 86-89, https://doi.org/10.1038/nclimate2483, 2015.
Takala, M., Luojus, K., Pulliainen, J., Derksen, C., Lemmetyinen, J., Kärnä, J.-P., and Koskinen, J.: Estimating northern hemisphere snow water equivalent for climate research through assimilation of space-borne radiometer data and ground-based measurements, Proc. Spie., 115, 3517-3529, https://doi.org/10.1016/j.rse.2011.08.014, 2011.

Taylor, K. E., Stouffer, R. J., and Meehl, G. A.: An Overview of CMIP5 and the Experiment Design, B. Am. Meteorol. Soc., 93, 485-498, https://doi.org/10.1175/BAMS-D-11-00094.1, 2012.

Thackeray, C. W., Fletcher, C. G,. Mudryk, L. R., and Derksen, C.: Quantifying the uncertainty in historical and future simulations of Northern Hemisphere spring snow cover, J. Climate, 29, 8647-8663, https://doi.org/10.1175/JCLI-D-16-0341.1, 2016.

Tilling, R. L., Ridout, A., Shepherd, A., and Wingham, D. J.: Increased Arctic sea ice volume after anomalously low melting in 2013, Nat. Geosci., 8, 643-646, https://doi.org/10.1038/ngeo2489, 2015.

Tivy, A., Howell, S. E. L., Alt, B., McCourt, S., Chagnon, R., Crocker, G., Carrieres, T., and Yackel, J.: Trends and variability in summer sea ice cover in the Canadian Arctic based on the Canadian Ice Service Digital Archive, 1960-2008 and 1968-2008, J. Geophys. Res., 116, C03007, https://doi.org/10.1029/2009JC005855, 2011a.

Tivy, A., Howell, S. E., Alt, B., Yackel, J. J., and Carrieres, T.: Origins and Levels of Seasonal Forecast Skill for Sea Ice in Hudson Bay Using Canonical Correlation Analysis, J. Climate, 24, 13781395, https://doi.org/10.1175/2010JCLI3527.1, 2011 b.

Tucker III, W. B., Weatherly, J. W., Eppler, D. T., Farmer, L. D., and Bentley, D. L.: Evidence for rapid thinning of sea ice in the western Arctic Ocean at the end of the 1980s, Geophys. Res. Lett., 28, 2851-2854, https://doi.org/10.1029/2001GL012967, 2001.

Turcotte, R., Fortin, L. G., Fortin, V., Fortin, J. P., and Villeneuve, J. P.: Operational analysis of the spatial distribution and the temporal evolution of the snowpack water equivalent in southern Québec, Canada, Hydrol. Res., 38, 211-234, 2007.

Verseghy, D., Brown, R., and Wang, L.: Evaluation of CLASS Snow Simulation over Eastern Canada, J. Hydrometeor., 18, 12051225, https://doi.org/10.1175/JHM-D-16-0153.1, 2017.

Vincent, L., Zhang, X., Brown, R., Feng, Y., Mekis, E., Milewska, E., Wan, H., and Wang, X.: Observed trends in Canada's climate and influence of low-frequency variability modes, J. Climate, 28, 4545-4560, 2015.

Wrzesien, M. L., Durand, M. T., Pavelsky, T. M., Kapnick, S. B., Zhang, Y., Guo, J., and Shum, C. K.: A new estimate of North American mountain snow accumulation from regional climate model simulations, Geophys. Res. Lett., 45, 1423-1432, https://doi.org/10.1002/2017GL076664, 2018.

Zhang, Y., Chen, W., and Riseborough, D. W.: Modeling the longterm dynamics of snow and their impacts on permafrost in Canada, in: Ninth International Conference on Permafrost, proceedings volume 2, edited by Kane, D. L. and Hinkel, K. M., Institute of Northern Engineering, Fairbanks, USA, 2055-2060, 2008. 